\title{
"THE SPRING OF LOVE AND INSPIRATION" EXHIBITION: FROM THE GENERATION OF AN IDEA TO ITS IMPLEMENTATION
}

\author{
Maria Yurievna Filatova, \\ State Museum of the East, \\ 12A Nikitsky Boulevard, Moscow, 119019, Russian Federation, \\ fima2018@yandex.ru.
}

\begin{abstract}
The article highlights the features, characterizing the artists' works at the exhibition "The Spring of Love and Inspiration", dedicated to the 100th anniversary of the TASSR. This was a joint project of the Kazan Kremlin State Museum-Reserve and the Moscow Mardjani Foundation. The purpose of this study is to identify the features of national identity manifestations found in the artists' works presented at this exhibition. The article proves that some artists, concentrating on the national worldview peculiarities, create their own ethnic microcosm with its history, nature, mythology, language, and other attributes, while others push the boundaries of their artistic world to create common Turkic images.
\end{abstract}

Key words: Tatars, fine arts, Mardjani Foundation, Tatar artists, national identity.

In September 2020, the exhibition "The Spring of Love and Inspiration. Works of Tatar Artists from the Collection of the Mardjani Foundation" was opened in the Kazan Manege. This is another joint project of the Kazan Kremlin State MuseumReserve and the Moscow Mardjani Foundation. It must be said that the Foundation is actively working in Kazan, fruitfully cooperating with museums and institutes, participating in large-scale exhibitions at various venues and organizing its own projects. From September to November, thanks to the support of the leadership of the Hermitage-Kazan Center and the invaluable help of its staff, works from the collection of the Mardjani Foundation were presented in both spacious and cozy venue of the Manege

"The Spring of Love and Inspiration" is the third exhibition opened within the framework of the project dedicated to the 100th anniversary of the TASSR. The first two expositions of the series turned out to be more geographically local and were dedicated to the Tatar artists of St. Petersburg: in June 2020, an exposition presented a group of eleven contemporary masters, and then, in July - August, a personal exhibition of the painter Azat Galimov was held.

The general name of the project - "Invisible Ties with the Motherland" - explains its program and basic idea. Since ancient times, Tatars have traveled all over the world, finding themselves far from their historical homeland. The reasons could be different - both political and personal. Eventually, some of them returned home, others left their country forever ([Gilyazov], [Mashakova, Habutdinova], [Habutdinova, Zamalieva],
[Habutdinova], [Usmanova], [Safin, Habutdinova, Habutdinov], [Faezova, Habutdinova, Gainullina], etc.). But wherever the representatives of the Tatar people find themselves - even those who were born outside Tatarstan - to this day they cherish and pass on culture, traditions, language, and awareness of their national identity to their descendants. This is how the people's cultural code, formed over many centuries, has been preserved and is manifesting itself in the images of literature, music and, of course, in fine arts (see: [Nigmatullina, 2002], [Nigmatullina, 2014, No. 1], [Nigmatullina, 2014, No. 2 ].

Tatarstan has thus become the "spring of love and inspiration" for many of the authors, whose works from the collection of the Foundation, were presented at the exhibition. Their whole biographies or individual episodes of life are somehow connected with this land. Some artists were born here, others came or come here to work, to organize exhibitions. Keeping the memory of their ancestors in their hearts, they turn to Tatar history, poetry, folklore, and ancient archetypes, hidden in everyone's soul. The main thing for all artists is the feeling of belonging to their people, which invariably feeds their creativity.

The Mardjani Foundation brought sixty works by sixteen authors to Kazan. In the course of the preparation for the exhibition, several works have been specially restored by the Foundation. These are: a small impressionistic still life with flowers by Baki Urmanche and the works of Adiya Sitdikova.

The exposition turned out to be dynamic and varied: paintings, graphics, and sculptural compo- 
sitions were there next to each other. The exposition was devoted to the Tatars who worked in the $20^{\text {th }}$ century and continue working today. The geography of their life paths is vast: China, Uzbekistan, Kazakhstan, Latvia, Bashkortostan, Perm, Moscow, and St. Petersburg. Both our contemporaries and masters of past generations, whose names have long occupied an honorable place in the history of art, were displayed side by side at the exhibition. With all the variety of genres - landscapes, still lifes, portraits, subject compositions, and styles - from realism to abstraction, the exposition turned out to be very integral. The works were selected in line with the general idea: the history of the people, ancient Turkic legends and mythological images, and native nature. Even everyday plots, costumes, and types of the characters portrayed were mostly ethnically colored. This choice of works proves once again that a seemingly narrow range of themes and motifs nevertheless contains unlimited possibilities for interpretation.

The works of most of the authors at the exhibition were familiar to the Kazan audience, but the Mardjani Foundation tried to bring new exhibits to Kazan. Regular visitors to exhibitions know how important the exposition context is for perception, sometimes making well-known things sound in a new way. Therefore, some of the Baki Urmanche and Chingiz Akhmarov's works, which were probably remembered from the time of their personal exhibitions, were presented in a new setting. These masters, who worked in the friendly republics of Central Asia, each in their own way, illustrate the theme of strong ties with their historical homeland.

The open space of the Manege, symbolically divided into two halls, helped to organize the exposition according to the geographical principle: Tatar artists in Central Asia and those of their fellow countrymen whose life and work are associated with Bashkortostan, the Baltic States, Perm, Moscow, and St. Petersburg.

Central Asia and, to a greater extent, Uzbekistan are connected with Tatarstan and the Tatars by centuries-old versatile relations. Throughout its history, Volga Bulgaria had close ties with Khorezm, Bukhara, and other cities. In the $13^{\text {th }}$ $15^{\text {th }}$ centuries, the ancestors of the modern Tatars and Uzbeks were the main population of the powerful Golden Horde - both urban and nomadic. Later, Tatar merchants and diplomats played an important role in establishing political and trade contacts between Russia and the Kokand and Khiva khanates, and with the Bukhara Emirate. In the $18^{\text {th }}-19^{\text {th }}$ centuries, many Tatars were educat- ed in the madrasahs of Bukhara and Samarkand. Among them were the future world famous Tatar theologians and religious figures, scientists and educators: Gabdennasyr Kursavi, Shigabutdin Mardjani, Utyz Imiani, and Murad Ramzi. As permanent residents, the Tatars of the Volga region began to settle in the territory of modern Uzbekistan at the end of the $18^{\text {th }}$ century.

A vivid example of such invisible unity with the homeland is the biography of such a large-scale and progressive personality as Shigabutdin Mardjani - a theologian and educator, ethnographer, orientalist, and teacher (see: [Khamidullin]). He was born into a respected family of Muslim priests in Tatarstan in the village of Yabynchi in 1818. After studying at the madrasah, Mardjani went to master the spiritual riches of Islam in Turkestan, to the famous centers of Muslim education - Bukhara and Samarkand, and returned to his homeland ten years later in 1849 .

Representatives of the large Tatar community, who have preserved their cultural traditions, still live in Uzbekistan. Tatar artists play an important role in the art of Uzbekistan.

In the exposition of the first hall, Baki Urmanche's pasty rich paintings entered into a dialogue with the delicate and graphically elegant works of Chingiz Akhmarov. The Central Asian flavor was emphasized by poetic watercolors by Marat Sadykov, early graphic portraits of the austere style and later illustrative works by Ravil Khalilov.

Baki Urmanche (1897-1990) is perhaps the most famous artist in Tatarstan. This time the exhibition did not include the frequently displayed and well-known canvases of his early period. The exposition of his work presented the canvases executed during his long stay in Kazakhstan and Uzbekistan. In Central Asia, this wonderful master is also revered. His works can be found in many museums, thanks to him the sculpture faculty was opened at the Tashkent Art Institute. Urmanche was an Honored Artist of the Kazakh SSR.

Baki Urmanche was born in the village of KulCherken (Cherki-Grishino) in the Tetyushsky district of the Kazan province (now the Buinsky district of Tatarstan). The artist's long life was eventful, his creative legacy is huge and diverse. He was very attached to Tatarstan, but he constantly had to leave his homeland to invariably come back.

In his youth, Urmanche was a miner in Donbass, a teacher in the Tambov region, and a worker at the Nadezhda factories in the Urals. During World War I, he served in Turkestan with the 
tsarist army. This was his first trip to Central Asia. The artist recalled that it was there that in the hands of the captured Austrians he saw paints and brushes ...

After the revolution, Urmanche served in the Red Army during the Civil War - first in Kazan, then in Moscow. He became the first Tatar artist to receive a higher professional education: in 1919 he completed a course at the Kazan Art Workshops, and later, in 1926, he graduated from the VKHUTEMAS in Moscow. After graduation, Urmanche returned to Kazan and became the head teacher and the teacher of the Art School, then its principle. He was engaged in painting, organized art and ceramic workshops, illustrated books, wrote articles, and delivered lectures.

In 1929, Urmanche was caught in the first wave of Stalinist repressions. Together with his younger brother Khadi, he was sent to the Solovetsky Special Purpose Camp. He returned five years later, but without his brother. After that, the artist found himself in Moscow, where he participated in preparations for the opening of the AllUnion Agricultural Exhibition, and was admitted to the Union of Artists of the USSR.

In 1941, Urmanche received an invitation to come to Alma-Ata to prepare for the centenary celebrations of the Kazakh poet Abai. When the war broke out, he was in Semipalatinsk, in the places where Abai used to live. In Kazakhstan, where Urmanche was highly revered, he was to live for several years. The Kazakhs would say about him: "Urmanche is our artist".

In Kazakhstan, and later in Uzbekistan, where Urmanche soon moved, he lived until 1956, and this was a special period of the artist's work. Many wonderful paintings were created there: landscapes, genre paintings, a portrait gallery of local figures of history and culture, historical canvases, and illustrations for books. In addition, Urmanche was engaged in scenography, created bas-reliefs, panels, various sculptural compositions, and worked on projects of monuments.

The artist could not live in Alma-Ata all the time because of his past. As an untrustworthy citizen, he was forced to leave the capital of the republic. Urmanche left for Uzbekistan, settled in Samarkand, where his sister was living at that time. The bright colors of Uzbekistan inspired the artist to create canvases, saturated with the sun. Despite the difficulties, Baki Urmanche was always distinguished by his active attitude to life. So, in Uzbekistan, he was one of the initiators of opening the faculty of sculpture at the Tashkent Art Institute.
In 1956, Urmanche returned to Kazan. He continued to work fruitfully, retaining a great interest in life, which is felt in all of his works. The works of Baki Urmanche uniquely combine European and Eastern traditions. He observed various manifestations of Turkic culture not only in his native Tatarstan, but also in Bashkiria, Uzbekistan, Turkmenistan, and Kazakhstan - everywhere he went during his long life.

"The Knight of the Oriental Lady" - this is the nickname of Chingiz Akhmarov, one of the iconic masters of Uzbekistan (1912-1995), a People's Artist of Uzbekistan and Tatarstan. Akhmarov is the author of numerous easel works, sketches of scenography for films and book illustrations, an excellent portrait painter, professor, and teacher, who left the concept of "Akhmarov's School" in the history of art. The artist created many mosaics and frescoes that adorn the interiors and facades of buildings not only in Uzbekistan, but also in Russia. He was born in the South Urals, in the city of Troitsk. In 1927, the family moved to Samarkand. The young Chingiz Akhmarov arrived there after completing his studies at the Perm Art School. Akhmarov visited Russia more than once; in 1955 he received important order for an authorial piece of work: it was required to single-handedly, without assistants, decorate the interiors of the building of the Opera and Ballet Theater in Kazan. This huge work, lasting for more than two years, was difficult to implement due to its creative concept. He designed the interiors of the Kazan railway station, unfortunately not preserved. In 1960, the artist made a ceramic panel for the Kazan River Port, which can be seen today.

Chingiz Akhmarov's art is very lyrical, it is the world of beauty and poetry. Female images are among the main themes of his works and he admires his models, emphasizing the natural grace with refined graphics of their silhouettes. His characters - real Tatar and Uzbek girls, as well as their collective images - personify the refined and mysterious East. Among the Tatar images, the exhibition showed the work "Based on the Poetry of Dardmend" - a brooding girl, wearing a Tatar headdress, is sitting at the grave. On the tomb, in Arabic script, a quote from the poem "I could not sprinkle the shroud" is inscribed:

Burning with love were Majnun and Farhad, Having passed through the flames, they found fame, I, who was burned by the fire a hundred times, At home, was not believed to have been burning! 
Another work was "Syuyumbike with Her Son Utyamishgirey". The artist painted this favorite semi-legendary image, which could be found several times in different interpretations at the exhibition. Many artists are attracted by the life story of Syuyumbike - a symbol of the outgoing Golden Horde civilization, the woman who played an important role in the history of Tatarstan, simultaneously being its victim. Akhmarov created a composition similar to ceremonial portraits of noble persons, but used a non-classical light color scheme with a predominance of blue and green hues.

The exhibition also showed sketches of murals at the Musa Jalil Opera and Ballet Theater in Kazan. Unfortunately, the murals themselves were lost during the restoration of the theater building.

Among the contemporary Tatar artists from Uzbekistan, the watercolorist Marat Sadykov is very famous. He was born in 1945 in Bukhara. This amazing ancient city and the nature of Uzbekistan became the main themes of his work. Here, the artist discovered the world of local everyday life, a traditional world, not particularly remarkable, but full of unique charm. As Marat himself says: "I somehow immediately understood that watercolor was in my line, I fell in love with it for its transparency and lightness. And, in my opinion, Bukhara landscapes turn out better when you paint them with watercolors - the architecture of Bukhara becomes more expressive, there is more airiness in the landscapes and sliding shadows are more clearly outlined".

For many years Marat Sadykov has been living in Tashkent. The artist's family - his wife and daughter - are also professional painters. Sadykov is a recognized Tatar artist in Uzbekistan, his works can be frequently seen at exhibitions and his bright spacious workshop is full of his lyrical watercolors.

A friend of Marat Sadykov was another artist, Ravil Khalilov, who happened to be in Uzbekistan for a certain period of time (1941-2006). Ravil was born into the family of a Tatar merchant and teacher in the small Chinese town of Kuldzha in the Ili River valley, separated from the Soviet Union by a frontier post and by the Tien Shan from China. He went to a Tatar school and later graduated from the Beijing Academy of Arts. In 1963, the family moved to Chimkent and Ravil continued his education at the Tashkent Art and Theater Institute. Khalilov also worked in the watercolor technique, his manner was distinguished by special sophistication, especially in landscapes, which were subtle and poetic. He moved to Moscow in 1978. The impressions of childhood and adolescence influenced Khalilov's work no less than education. The master gained fame as an illustrator of many books - epic, folklore, and children's fairy tales. He also did painting, in later years creating several series of disturbing, dramatic easel canvases, one of which is dedicated to the Chernobyl tragedy. Shortly before his death, the artist began working on illustrations for the book "Religious Poetry of the Tatars", which, unfortunately, remained unfinished.

The second section of the exposition was more extensive. It presented the painter Amir Timergaleev and the sculptor Tagir Subkhankulov, both living in Moscow, the artist from St. Petersburg Marat Vafin, the Perm sculptor Alfiz Sabirov, and Ramin Nafikov, who studied in Latvia and often goes there. Several Tatar artists live in Ufa Anvar Kashaev, Rinat Minnebaev as well as Vasil Hannanov, Rinat Kharisov, Midat Mukhametov, and Rasikh Akhmetvaliev, members of the "Genghis Khan" group. Adiya Sitdikova worked in Ufa too.

The painter Amir Timergaleev was born in 1955 in Kazan. After completing his course at the Kazan Art School, he continued his education at the Moscow Institute named after V. Surikov. His manner can be described as "free figurativeness"; the works are intimate and bright at the same time. He paints landscapes, including urban landscapes, still lifes, and portraits. He improvises, creatively reinterpreting the heritage of world culture. Today, Amir Timergaleev lives and works in Moscow, he is undoubtedly a prominent representative not only of Tatar, but also of European art. One of Timergaleev's works, "Landscape. Kazan", depicting Bauman Street, was especially admired by the audience, reminding them of the recent past. The artist painted this canvas in 2008 - apparently, from memories. Judging by the signs of the shops, Kazan residents at the exhibition came to the conclusion that the street looked like this a little earlier, in the late 1990s.

The Petersburg resident Marat Vafin (born 1962) devoted his works to the Volga Bulgaria, whose culture is the Tatar people's heritage. The artist is interested in everything related to the history of this once powerful state, including its religion - Tengrianism. Vafin mostly works in series, creating multi-part compositions on one theme. His painting is pasty, relief, and he sometimes uses garlic to strengthen the painted surface, mixing its juice into paints. The exhibition featured four works from the twenty-part pictorial polyptych 
"The Star River". The artist made dozens of draft drawings for each work in search of the only possible compositional design. Vafin's works have been shown many times in Kazan. In 2016, the paintings of the series "Restoration of the Great Bulgarian Minaret. Five Prayers" brightened up the exhibition "The Travel of Ibn Fadlan: the Volga Route from Baghdad to Bulgar" in the HermitageKazan Center.

At the exhibition, Tatar artists from Bashkortostan were represented by several names. Perhaps the most famous creative association in Ufa is the "Genghis Khan" group. The association was founded in 1990 and it still exists, now headed by Vasil Khannanov. His works have been shown more than once in the capital of Tatarstan. Vasil was born in 1956 in the city of Oktyabrsky (the BASSR). Hannanov's work is fertile ground for art critics' interpretations. But, according to the artist himself, all his works are his own story, and the choice of plastic solutions is determined by what torments and worries him at a certain period of his life. He assesses the results of his work strictly, heeding to the reaction of the audience. Freedom is felt in all his works. Hannanov's paintings and drawings are stylistically diverse - from realism to non-objectivity. He bases his works on ancient myths, the Koran, the Old and New Testaments, and folk art. Throughout his career, the artist has often used common Turkic motifs, as well as the images taken from the history of Tatarstan. The exhibition showed the artist's two paintings created in the 1990s: the symbolic "Composition No. 12b (The Great Steppe)" from the cycle "The Birth of a Myth" and "Syuyumbike". The eye-catching "Syuyumbike", executed in a dark laconic color scheme, attracted the visitors of the exhibition not only by the beauty of its implementation. The artist managed to create a mysterious image, a secret hidden in the mists of time. The image of Syuyumbike lacks the softness and lyricism that we see in the picture of Chingiz Akhmarov. The woman is sitting on a carpet in an abstract empty space, her eyes are closed. She hugs her son, with a protective gesture; she covers the boy's hand with her palm with long graceful fingers, studded with rings. Her son, Utyamyshgirey, whose face resembles a Fayum portrait, stares at the viewer. There is a child still open to the world - and, turning away from this world, there is a pensive young woman who has survived a lot...

Another Ufa artist, Rinat Kharisov, interprets the image of Syuyumbike in his own way. The poster similarity, unusual for such a theme, en- hances the drama of the plot. The weeping queen of Kazan soars skyward, crossing the falling-at-anacute- angle tower, named after her. The general feeling of tragedy is enhanced by the contrast of sharp corners, intersecting diagonals, and elements of Tatar floral ornament, which can be found in many works by Kharisov. Syuyumbike becomes a symbol, a marker of the era. The same symbols, but already religious ones, are depicted by the artist in his work "The Kazan Kremlin" - the Spasskaya tower with a five-pointed star, the Christian cathedral, and the Syuyumbike tower, crowned with a crescent moon - the emblem of Islam, with their peaks cutting into the sky, crossing each other.

Rinat Kharisov, who is also a member of the "Genghis Khan" group, was born in 1953 in the village of Lenin-Bulyak, the Buraevsky district, the BASSR. Taking primitive stylistics as a basis for his work, the artist relies on the traditions of Tatar folk arts and crafts. Embroidery, house paintings, shamails with their ornamentation are the rural and urban provincial cultures of the mid- $20^{\text {th }}$ century familiar to the author since his childhood. Texts in Russian, Tatar, and Arabic, resembling signs and banners, play an important role in Kharisov's works. Thus, his painting "A Black and White Film" (2002) has the inscription in Tatar, translated as follows: "Today our village club will show the film "The Square Peg". Comrades, the film is very good, come and see it!"

Ghost horsemen, beautiful ladies, and distant cities are the subjects of Rasikh Akhmetvaliev's works. He was born in 1956 in the village of Bekeevo, the Chishminsky district of Bashkiria. Rasikh Akhmetvaliev is a visionary artist. His intimate canvases are enigmatic visions, in which aesthetics and harmony become the dominant qualities. The exhibition showed the mythical horsemen, executed in the characteristic painting style and with characteristic elements of the plot, but for this artist the works turned out to be unusually bright in color. The riders of Akhmetvaliev are not a personification of strength, might, and warlike principles, their content is much more complex and meaningful. These images are both Turkic and, at the same time, worldwide.

They can be compared to mirages and visions that sometimes appear in a cloudy sky and in which we try to recognize familiar shapes. Rasikh experiments with color and light. His canvases are textured and multi-layered. The smooth surface is combined with the seemingly sculpted shapes. With the help of transparent glazes in combination 
with pasty strokes, he creates a pearly surface in which shades of green, blue, and yellow gently blend into each other. The texture and lightness of his work resemble the half-erased frescoes that used to adorn ancient dwellings. When creating his canvases, Rasikh often uses light pastel shades.

For several decades, the painter and graphic artist Midat Mukhametov (born 1955) has made the steppe the main subject of his works. His homeland is the village of Mustafino, the Sharlyk District in the Orenburg Region. Mukhametov, who grew up in the open spaces of the steppe, has a special spatial perception, which is clearly manifested in his meditative paintings. In his works, he gradually moves from the landscapes of certain places to a broader understanding of the steppe, creating images akin to cosmic ones. Balancing on the verge of realism and abstraction, Midat transforms everything that a traveler might encounter human figures, gravestones - into anthropomorphic geometrized signs, and the entire landscape becomes a single rhythmically organized substance. Midat gravitates towards monochrome, dark green, brown, ocher shades characteristic of the steppe. Pathetics is alien to the artist. In his works, the steppe is melancholic and viscous. However, melancholy here is not a human emotion, but rather an intrinsic property of the landscape. The steppe is fertile ground for abstract art. In fact, it is non-objective in itself. This is a mysterious entity that lives by its own laws.

The painter and graphic artist Anvar Kashaev was born in 1949 in the village of Akbulat, the Fedorovsky district of the BASSR. At the age of 15, Anvar left for Central Asia. In Chimkent (South Kazakhstan) he worked as a concrete worker, he was a bricklayer in Tashkent and participated in the restoration of the city after the 1967 earthquake; later, he worked on a construction site in Dushanbe. There, he entered an art school as a volunteer, and in 1969, he returned to Bashkiria and completed his education at the Ufa Art School. Kashaev's painting is dim, intimate, and poetic. His favorite genre is deserted landscapes. The main characters are nature, transparent air, and the artist himself, subordinated to this natural rhythm as an integral part of the universe: "it is not asphalt, but the heaven and earth which give birth to artists". The source of inspiration for him is a nook near the southern spurs of the Ural Mountains. He uses the same motifs, painting them at any time of the year, being in different moods, and each time creating a new work, different from other ones. This is how Hokusai depicted his "Thirty-Six Views of Mount Fuji".
Anvar's works are akin to the art of Far Eastern artists. And next to his easel, there is always an album of Old Russian paintings. Anwar believes that icons and works of Chinese masters are akin in spirit.

Rinat Minnebaev (born 1964), well known in Kazan, is one of the leading masters of contemporary art in the Volga and Ural regions. Panels, executed in a unique technique of hand-cast paper (the series "Ibn Fadlan's Journey to the Itil River") fit organically into the archaeological exhibition "Ibn Fadlan's Journey: The Volga Route from Baghdad to Bulgar", held in 2015 in the halls of the Hermitage- Kazan Center. Minnebaev is a graduate of the Graphic Arts Department at the Bashkir Pedagogical Institute. His works abound in conventional elements full of hidden meanings that can be referred to the archetypes of the ancient Turkic culture. The exhibition features early etchings from "The Masks of the Gods" series. They artist conveys the mystical connection between man and nature. Since his youth, archeology has been Rinat's passion. In his etchings with the images of the first ancestors, the author consistently moves towards more and more abstract laconic signs. He transforms the perception of time by transporting the viewer to the era of deep antiquity.

The fate of the artist Adia Sitdikova (19132000), the only female artist at the exhibition, is unusual. She started painting when she was in her forties, but she was able to become a professional painter.

Adia Sitdikova was born in Tatarstan, the village of Mordva, the Agryz district. At 16, she left her village for Central Asia, then for Moscow. In 1934, she came and stayed in Ufa. In the 1950s, Sitdikova got a job at the Art Foundation as an auxiliary worker, and this determined her future life. In adulthood, between washing windows and rearranging other people's canvases, she took painting lessons in an art studio. Soon her talent was noticed, her works were shown at exhibitions. Intuitively, the artist acquired her own style, based on ethnic motifs familiar to her since childhood these are Tatar towels and curtains with folk ornaments, Bashkir honey and chak-chak - symbols of home comfort and well-being. By the way, Adiya is an excellent embroiderer and dressmaker. Now Adiya Sitdikova, who has got many state awards, is one of the most significant artists in Bashkortostan.

Visitors to the exhibition, familiar with the works of local Kazan artists, might ask a question: why the exhibition, which presents the artists 
working outside Tatarstan, shows the works of Ramin Nafikov. Ramin (born 1967) lives in Kazan. $\mathrm{He}$ is a hereditary painter, his father Hanafi Nafikov is an Honored Artist of the Republic of Tatarstan. After completing his course at the Kazan Art School, Ramin continued his education at the Latvian Academy of Arts, and this fact largely determined his creative development. The artist constantly travels and lives outside Kazan for a long time. His constant movement between the West and the East (Kazan - Riga - Vienna) has become not only Ramin's exhibition geography, but also a kind of his artistic strategy. Nafikov's works combine European artistry and Eastern energy. They are energetic in color and composition. At first glance, they seem to be completely abstract. However, in these seemingly chaotic lines and color spots, the audience, sometimes intuitively without looking at the name label, guess the stories of the paintings. The artist himself defines his style as "expressive formalism".

The central space of the exhibition was given to plastic forms. The Mardjani Foundation brought the works of two sculptors to the exhibition: Tagir Subkhankulov from Ufa, who lives in Moscow, and Alfiz Sabirov, who works in Perm.

Tagir Subkhankulov was born in 1954 in the village of Eremeevo, the Chishminsky district of Bashkiria. Having completed his course at the Graphic Arts Faculty of the Moscow Pedagogical Institute named after V. Lenin, he decided to stay in the capital. Tagir works equally well with bronze, stone, wood, plastic, and clay. He creates miniatures, urban monuments, realistic figures, and abstract forms. His works echo the art of both ancient Egypt and modernity of the early $20^{\text {th }}$ century with its fluidity of forms and the subtle play of silhouettes, the desire to capture the fleeting facial expression and body movement. The beauty of the female body is one of the priority themes in Tagir's works. The sculptor's wife became the model for some of the works, including those shown at the exhibition. "My Buryatka" - he calls her lovingly. The outward appearance of his models is not perfect, they are earthly beings, chaste in their nakedness. He does not seek to achieve portrait likeness. These are, rather, abstract images that embody a generalized idea of the natural feminine element. Tagir skillfully uses the texture of stone, wood, and bronze, without smoothing the surface to gloss. Even bronze, a material cold by nature, takes on warmth in his works.

Tagir became the author of several wonderful works created for urban spaces and public institu- tions. He is the author of the sculptural composition "A Mermaid", installed in front of the National Cultural Center of Kazan, the statuette - the prize of the International Muslim Film Festival "The Golden Minbar", the prize of the Foundation for Spiritual Revival "Rukhiyat", and the sculpture "Akbars", the symbol of Tatarstan.

The sculptor Alfiz Sabirov, the youngest participant of the exhibition, was born in the small village of Ishimovo in the Kama region in 1985. A graduate of the Ilya Glazunov Russian Academy of Painting, Sculpture, and Architecture, he became a laureate of the Baki Urmanche Prize of the Ministry of Culture of the Republic of Tatarstan in 2017. Sabirov's works have already gained fame both in Russia and abroad (see [Khabutdinova, Zamaliev]). National motifs, mythology, and even cosmic forms are closely intertwined in Alfiz's works. This is the world of fantastic animals, heroes, and gods, which comes into contact with modernity. The artist creates both small plastic forms, making works of bronze bordering on jewelry, and fairly large forms. Sometimes, Alfiz experiments combining different materials in one sculpture. He admits that he cannot give an exact definition of his style: "The most interesting variant is "new artifact'. It is based on ancient artifacts, those things that were found during excavations; once, they were objects of rituals and have come down to us as a form of art, as fragments and chips. I consider the structural elements of legends and myths to be a state of life - parts of something bigger".

The exhibition "The Spring of Love and Inspiration. Works of Tatar Artists from the Collection of the Mardjani Foundation" vividly demonstrated how diverse is the art of Tatar artists who left their homeland for some time or were born outside Tatarstan. Some of them focus on the features distinguishing their national worldview and create their own ethnic microcosm with its history, nature, mythology, language, and other attributes. Others push the boundaries of their artistic world to create common Turkic images. Undoubtedly, the environment influences creative individuals. These are travel, a change of place of residence, and of course, their memories of childhood and youth, folk art, the culture of the people to whom they belong. This explains the integrity of the exhibition, which presented the works by representatives of Tatar culture of different generations, different fates, and views.

\section{References}

Faezova, L. R., Habutdinova, M. M., Gainullina, G. R. (2018). The Emigration Theme in Tatar Literature. 
Modern journal of language teaching methods. Vol. 8, Is. 9, pp. 66-71. (In English)

Gilyazov, I. A. (1998). Na drugoi storone. Kollaboratsionisty iz povolzhsko-priural'skikh tatar $v$ gody Vtoroi mirovoi voiny [On the Other Side. Collaborators from the Volga-Ural Tatars during the Second World War]. 252 p. Kazan', Master-Lain. (In Russian)

Hamidullin, B. L. (2018). Shigabutdin Mardzhani: ot sredneaziatskikh "universitetov" $k$ ideologii tatarskoi natsii "novogo vremeni" [Shigabutdin Mardjani: From Central Asian "Universities" to the Ideology of the Tatar Nation of "Modern Times"]. Tatarica. No. 1 (10), pp. 157-163. (In Russian)

Habutdinova, M. M., Zamalieva, L. F. (2019). Splav arkhaiki i sovremennosti v tvorchestve skul'ptora Al'fiza Sabirova [The Fusion of Archaic and Modern Features in the Sculptures by Alfiz Sabirov]. M. M. Khabutdinova, L. F. Zamalieva. Tatarica. No. 13(2), pp. 126-139. (In Russian)

Həbetdinova, M. M. (2019). F. Bayromovanym "hiæçrət" (2017) romanynda tatar emigratsiyase temasy [The Theme of Tatar Emigration in Bayramova's Novel "Hijrat" (2017)]. Fənni Tatarstan. No. 2, pp. 35-45. (In Tatar)

Mashakova, A. K., Habutdinova, M. M. (2016). K voprosu ob etnicheskoy samoidentifikatsii tatar Kazakhstana (na materiale liriki sovremennykh tatarskikh poetov) [On the Self-identity of Kazakhstan Tatars (based on the lyrics of modern Tatar poets)]. Tatarica. No. 1, pp. 59-71. (In Russian)

Nigmatullina, Yu. G. (2002). “Zapozdalyi modernism" v tatarskoi literature i izobrazitel'nom iskusstve ["Late Modernism" in Tatar Literature and Fine Arts]. 175 p. Kazan', Fən. (In Russian)

Nigmatullina, Yu. G. (2014). Tatavangard kak komponent "sredinnoi kul'tury" [The Tatar Avant-garde as a Component of the "Median Culture"]. Tatarica. No. 1(2), pp. 156-178. (In Russian)

Nigmatullina, Yu. G. (2014). Tatavangard: natsional'naia identichnost' i evraziiskoe samosoznanie [Tatar Avant-garde: National Identity and Eurasian Consciousness]. Tatarica. No. 2(3), pp. 185-203. (In Russian)

Safin, M. F., Habutdinova, M. M., Habutdinov, A. Iu. (2018). The Theme of Muhajirlik in Tatar Prose (El tema del muhajirlik en la prosa tartara). Opcion. Vol. 34, Is. 86, pp. 119-126. (In English)
Usmanova, L. (2007). The Turk-Tatar Diaspora in Northeast Asia: Transformation of Consciousness. A Historical and Sociological Account between 1898 and the 1950s. L. Usmanova. 367 p. Tokyo, Rakudasha. (In English)

Ufa. Tochka vozvrata (2016) [Ufa. The Point of Return]. Sost. M. Filatova. 215 p. Moscow, Fond Mardzhani, (In English)

\section{List of illustrations}

1. Adiya Sitdikova. Still Life with an Embroidered Towel. 1981. Paper, gouache, whitewash. 37x31.5. Mardjani Foundation

2. Vasil Hannanov. Syuyumbike-2. 1994. Oil on canvas. 146.5x97. Mardjani Foundation

3. Amir Timergaleev. Landscape. Kazan. 2008. Oil on canvas. 60x80. Mardjani Foundation

4. Anvar Kashaev. A Forgotten Village. 2006. Oil on canvas. $87 \times 121$. Mardjani Foundation

5. Marat Vafin. A Red Horse. Part 14 of the Polyptych the Star River. 2011. Oil on canvas. 50x150. Mardjani Foundation

6. Bucky Urmanche. Children in a Yurt. 1949. Oil on canvas. 60x50. Mardjani Foundation

7. Marat Sadykov. The Evening Conversation. 1997. Watercolor on paper. 49x60. Mardjani Foundation

8. Midat Mukhametov. The Walking One. 1995. Oil on canvas. $65 \times 110$. Mardjani Foundation

9. Ravil Khalilov A girl in red clothers. 1972. Paper, gouache. 69x59. Mardjani Foundation

10. Rinat Kharisov. Syuyumbike, the Queen of Kazan. 2009. Acrylic on canvas. 147x89. Mardjani Foundation

11. Ramin Nafikov. And So the Boat Is Sailing. 2007. Oil on canvas. 110x164. Mardjani Foundation

12. Chingiz Akhmarov. Syuyumbike and Her Son Utyamyshirey. 1992. Canvas, tempera. 100x80. Mardjani Foundation

13. Rinat Minnebaev. The White Wolf. From the series Masks of the Gods. 1995. Colored etching, aquatint. 41.5x53.5. Mardjani Foundation

14. Alfiz Sabirov. The Stricken One. 2018. Bronze. $22 \times 14.5 \times 10$. Mardjani Foundation

15. Tagir Subkhankulov. The Planet Earth. 2005. Bronze. 43x12.13. Mardjani Foundation 


\title{
ВЫСТАВКА «РОДНИК ЛЮБВИ И ВДОХНОВЕНИЯ»: ОТ ЗАМЫСЛА К ВОПЛОЩЕНИЮ
}

\author{
Мария Юрьевна Филатова, \\ Государственный музей Востока, \\ Россия, 119019, Москва, Никитский бульвар, д. 12А, \\ fima2018@yandex.ru.
}

\begin{abstract}
В статье раскрыта специфика работ художников на выставке «Родник любви и вдохновения», посвященной 100-летию ТАССР. Это совместный проект Государственного музеязаповедника «Казанский Кремль» и московского Фонда Марджани. Цель данного исследования - выявить особенности проявления национальной идентичности художников в работах, представленных на этой выставке. Доказано, что одни художники, концентрируясь на особенностях национального мировоззрения, создают собственный этнический микрокосм с его историей, природой, мифологией, языком и прочими атрибутами, а другие - расширяют границы художественного мира до общетюркских образов.
\end{abstract}

Ключевые слова: татары, изобразительное искусство, Фонд Марджани, татарские художники, национальная идентичность.

В сентябре 2020 года в казанском Манеже открылась выставка «Родник любви и вдохновения. Произведения татарских художников из коллекции Фонда Марджани». Это очередной совместный проект Государственного музеязаповедника «Казанский Кремль» и московского Фонда Марджани. Надо сказать, что Фонд активно проявляет себя в Казани, весьма плодотворно сотрудничая с музеями и институтами, участвуя в масштабных выставках на разных площадках и организуя собственные проекты. С сентября по ноябрь произведения из коллекции Фонда Марджани, благодаря поддержке руководства центра «Эрмитаж-Казань» и неоценимой помощи его сотрудников, были представлены в обширном и одновременно уютном пространстве Манежа.

«Родник любви и вдохновения» - третья выставка, открывшаяся в рамках проекта, посвященного 100-летию образования ТАССР. Две первые экспозиции серии оказались более локальны географически и были посвящены татарским художникам Санкт-Петербурга: в июне 2020 года открылась групповая экспозиция одиннадцати современных мастеров, а следом, в июле - августе, была проведена персональная выставка живописца Азата Галимова.

В общем названии проекта - «Незримые узы с Родиной» - заложены его программа и основная идея. С давних времен татары путешествовали по миру, оказываясь вдали от исторической родины. Причины могли быть разные - как политические, так и личные. Одни со временем возвращались домой, другие уезжали навсегда ([Гилязов], [Машакова, Хабутдинова],
[Хабутдинова, Замалиева], [Хәбетдинова], [Usmanova], [Safin, Khabutdinova, Khabutdinov], [Faezova, Khabutdinova, Gaynyllina] и др.). Но где бы ни оказались представители татарского народа - даже те из них, кто рожден вне Татарстана, - они и по сей день берегут и передают потомкам культуру, традиции, язык, сознание национальной идентичности. Так сохранился сформировавшийся на протяжении многих веков культурный код народа, явленный в образах литературы, музыки и, конечно, в изобразительном искусстве (см.: [Нигматуллина, 2002], [Нигматуллина, 2014, № 1], [Нигматуллина, 2014, № 2]).

Татарстан стал тем самым «родником любви и вдохновения» для многих представленных на выставке авторов работ из коллекции Фонда. Их биографии в целом или отдельные эпизоды жизни так или иначе связаны с этой землей. Одни художники здесь родились, другие приезжали или приезжают сюда работать, устраивать выставки. Храня в своей душе память предков, они обращаются к татарской истории, поэзии, фольклору, древним архетипам, подспудно живущим в душе каждого. Главным для всех мастеров остается чувство принадлежности к своему народу, неизменно питающее их творчество.

Фонд Марджани привез в Казань шестьдесят работ шестнадцати авторов. Несколько произведений были специально отреставрированы Фондом в процессе подготовки к выставке. Это небольшой импрессионистичный натюрморт с цветами Баки Урманче и работы Адии Ситдиковой. 
Экспозиция получилась динамичной и разнообразной: живопись, графика, скульптурные композиции соседствовали друг с другом. Экспозиция рассказывала о художниках-татарах, чье творчество пришлось на XX век и развивается в наши дни. География их судеб обширна: Китай, Узбекистан, Казахстан, Латвия, Башкортостан, Пермь, Москва, Санкт-Петербург. Соседствовали на выставке и мастера прошлых поколений, чьи имена давно заняли почетное место в истории искусства, и наши современники. При всем разнообразии жанров (пейзаж, натюрморт, портрет, сюжетные композиции), а также стилей (от реализма до абстракции), экспозиция получилась очень цельной. Отбор работ велся в русле общей идеи: история народа, древние тюркские легенды и мифологические образы, родная природа. Даже бытовые сюжеты, костюмы и типажи изображаемых героев по большей части были этнически окрашены. Такой выбор произведений в очередной раз доказывает, что, казалось бы, узкий круг тем и мотивов содержит тем не менее неограниченные возможности интерпретаций.

Большинство авторов, экспонируемых на выставке, знакомы казанскому зрителю по другим их работам, однако Фонд Марджани постарался привезти новые для Казани произведения, показанные здесь впервые. Постоянные посетители выставок знают, как важен для восприятия экспозиционный контекст, подчас заставляющий звучать по-новому хорошо известные вещи. Поэтому, например, некоторые произведения Баки Урманче и Чингиза Ахмарова, которые наверняка запомнились по персональным выставкам, оказались представлены в новом антураже. Эти мастера, работавшие в республиках Средней Азии, каждый по-своему иллюстрируют тему крепкой связи с исторической родиной.

Открытое пространство Манежа, условно разделенное на два зала, помогло организовать экспозицию, разделив ее по географическому принципу: татарские художники в Средней Азии и те их соплеменники, чьи жизнь и творчество связаны с Башкортостаном, Прибалтикой, Пермью, Москвой и Санкт-Петербургом.

Средняя Азия и в большей степени Узбекистан соединены с Татарстаном и татарами многовековыми разносторонними отношениями. Волжская Булгария на всем протяжении своей истории имела тесные связи с Хорезмом, Бухарой и другими городами. В XIII-XV веках предки современных татар и узбеков были ос- новным населением могущественной Золотой Орды - как городским, так и кочевым. Позднее татарские купцы и дипломаты сыграли важную роль в налаживании политических и торговых контактов России с Кокандским и Хивинским ханствами и с Бухарским эмиратом. В XVIIIXIX веках многие татары получили образование в медресе Бухары и Самарканда. Среди них будущие всемирно известные татарские богословы и религиозные деятели, ученые и просветители Габденнасыр Курсави, Шигабутдин Марджани, Утыз Имяни, Мурад Рамзи. В качестве постоянных жителей татары Поволжья стали селиться на территории современного Узбекистана в конце XVIII века.

Яркий пример незримого единения с родиной - биография такой масштабной и прогрессивной личности, как Шигабутдин Марджани богослов и просветитель, этнограф, востоковед и педагог (см.: [Хамидуллин]). Он родился в 1818 году в Татарстане, в селе Ябынчи, в уважаемой семье мусульманских священнослужителей. После учебы в медресе Марджани отправился постигать духовные богатства ислама в Туркестан, в прославленные центры мусульманского просвещения - Бухару и Самарканд, а на родину вернулся через десять лет, в 1849 году.

В Узбекистане и по сей день живут представители многочисленной татарской общины, сохранившие свои культурные традиции. Важную роль в искусстве Узбекистана играют и татарские художники.

В экспозиции первого зала пастозная насыщенная живопись Баки Урманче вступила в диалог с тонкими по колориту и графически изящными произведениями Чингиза Ахмарова. Среднеазиатский колорит подчеркнут поэтичными акварелями Марата Садыкова, ранними графическими портретами сурового стиля и более поздними иллюстративными работами $\mathrm{Pa}-$ вила Халилова.

Баки Урманче (1897-1990), пожалуй, самый прославленный художник Татарстана. В экспозиции на этот раз не было часто демонстрируемых и хорошо известных холстов. В экспозиции его творчество иллюстрировали произведения, написанные во время долгого пребывания в Казахстане и Узбекистане. В Средней Азии этот замечательный мастер также почитаем. Его работы можно встретить во многих музеях, благодаря ему был открыт факультет скульптуры в Ташкентском художественном 
институте. Урманче - заслуженный художник Казахской ССР.

Баки Урманче родился в деревне КульЧеркен (Черки-Гришино) Тетюшского уезда Казанской губернии (ныне Буинский район Татарстана). Долгая жизнь художника была полна событий, его творческое наследие огромно и разнообразно. Он был очень привязан к Татарстану, однако ему постоянно приходилось покидать родину, куда Урманче неизменно возвращался.

В юности Урманче был шахтером Донбасса, учителем на Тамбовщине, рабочим Надеждинских заводов на Урале. Во время Первой мировой войны в составе царской армии он служил в Туркестане. Это была его первая поездка в Среднюю Азию. Художник вспоминал, что именно там в руках у пленных австрийцев увидел краски и кисти...

После революции Урманче во время Гражданской войны служил в Красной армии - в Казани, потом в Москве. Он стал первым татарским художником, получившим высшее профессиональное образование: в 1919 году окончил Казанские художественные мастерские, а затем, в 1926-м, - ВХУТЕМАС в Москве. После института Урманче вернулся в Казань, стал завучем и преподавателем Художественной школы, затем ее руководителем. Занимался живописью, организовал художественнокерамические мастерские, иллюстрировал книги, писал статьи, читал лекции.

В 1929 году Урманче попал в первую волну сталинских репрессий. Вместе с младшим братом Хади его отправили в Соловецкий лагерь особого назначения. Вернулся он оттуда через пять лет, уже без брата. После этого художник оказался в Москве, где участвовал в подготовке к открытию Всесоюзной сельскохозяйственной выставки, был принят в Союз художников CCCP.

В 1941 году Урманче получил приглашение приехать в Алма-Ату для подготовки к празднованию столетнего юбилея казахского поэта Абая. Когда началась война, он был в Семипалатинске, в тех местах, где жил Абай. В Казахстане, где Урманче очень почитали, ему предстояло прожить несколько лет. Казахи говорили о нем: «Урманче - наш художник».

В Казахстане, а затем в Узбекистане, куда затем переехал Урманче, он прожил до 1956 года, и это особый период творчества художника. Здесь было создано множество замечательных произведений: пейзажи, жанровые карти- ны, портретная галерея местных деятелей истории и культуры, исторические полотна, иллюстрации к книгам. Кроме того, Урманче занимался сценографией, создавал барельефы, панно, разнообразные скульптурные композиции, работал над проектами памятников.

Художник не мог все время жить в АлмаАте: сказалось его прошлое. Как неблагонадежный он был вынужден покинуть столицу республики. Урманче уехал в Узбекистан, поселился в Самарканде, где в то время жила его сестра. Яркие краски Узбекистана вдохновили художника на создание насыщенных солнцем плотен.

В 1956 году Урманче вернулся в Казань. Он продолжал плодотворно работать, сохранив огромный интерес к жизни, что чувствуется во всех его произведениях. В творчестве Баки Урманче уникальным образом соединились европейские и восточные традиции. Разнообразные проявления тюркской культуры он наблюдал не только в родном Татарстане, но и в Башкирии, Узбекистане, Туркменистане, Казахстане - везде, где побывал за свою долгую жизнь.

«Рыцарь восточной дамы» - так называют одного из знаковых мастеров Узбекистана Чингиза Ахмарова (1912-1995), народного художника Узбекистана и Татарстана. Ахмаров - автор многочисленных станковых работ, эскизов сценографии к кинофильмам и книжных иллюстраций, прекрасный портретист, профессор, педагог, оставивший в искусствоведении понятие «школа Ахмарова». Художник создал множество мозаик и фресок, украсивших интерьеры и фасады зданий не только в Узбекистане, но и в России. Он родился на Южном Урале в городе Троицке. В 1927 году семья переехала в Самарканд. Туда же молодой Чингиз Ахмаров прибыл после учебы в Пермском художественном училище. Ахмаров не раз оказывался в России; в 1955 году он получил важный для него заказ на авторскую работу: нужно было единолично, без помощников, оформить интерьеры здания Театра оперы и балета в Казани. Эта огромная по объему и сложная по воплощению творческого замысла работа продолжалась более двух лет. Также он оформил интерьеры казанского железнодорожного вокзала, к сожалению не сохранившиеся. В 1960 году художник выполнил керамическое панно для речного порта Казани, которое можно увидеть и сегодня.

Искусство Чингиза Ахмарова очень лирично, это мир красоты и поэзии. Женские образы 
- одна из главных тем творчества художника, который любуется своими моделями, подчеркивая утонченной графикой силуэтов их природное изящество. Его персонажи - реальные татарские и узбекские девушки, а также их собирательные образы - олицетворяют изысканный и загадочный Восток. Среди татарских образов на выставке была показана работа «По мотивам поэзии Дэрдменда» - задумчивая девушка в татарском головном уборе, сидящая у могилы. На плите арабским шрифтом приведена цитата из стихотворения «Не сумел я окропить савана»:

Горели от любви Меджнун, Фархад,

Пройдя сквозь пламя, имя обрели,

Меня же, кто в огне пылал стократ,

На родине - горевшим не сочли!

Еще одна работа - «Сююмбике с сыном Утямышгиреем». Художник обращается к излюбенному полулегендарному образу, который еще несколько раз встретился в экспозиции в разных интерпретациях. Многих художников привлекает история жизни Сююмбике - символа уходящей золотоордынской цивилизации, женщины, сыгравшей важную роль в истории Татарстана и одновременно ставшей ее жертвой. Ахмаров создал композицию, напоминающую парадные портреты знатных особ, но использовал при этом неклассическую светлую цветовую гамму с преобладанием голубых и зеленых оттенков.

На выставке были показаны также эскизы росписей Театра оперы и балета имени Мусы Джалиля в Казани. Сами росписи, к сожалению, бесследно исчезли во время реставрации здания театра.

Среди современных татарских художников Узбекистана большую известность получил акварелист Марат Садыков. Он родился в 1945 году в Бухаре. Этот удивительный древний город и природа Узбекистана стали главной темой его творчества. Здесь художник открыл для себя мир местной повседневной жизни, мир традиционный, как будто ничем особо не примечательный, но полный неповторимой прелести. Сам Марат говорит: «Я как-то сразу определил, что акварель близка мне, я полюбил ее за прозрачность и легкость. И, по-моему, бухарские пейзажи лучше получаются, когда пишешь их акварельными красками - архитектура Бухары становится выразительнее, в пейзажах больше воздушности, четче вырисовываются скользящие тени».
Уже многие годы Марат Садыков живет в Ташкенте. Семья художника - жена и дочь тоже профессиональные живописцы. Садыков - признанный татарский художник в Узбекистане, его работы часто можно увидеть на выставках, а светлая просторная мастерская полна его лиричными акварелями.

Другом Марата Садыкова был еще один художник, на время оказавшийся в Узбекистане, Равил Халилов (1941-2006). Равил родился в семье татарского коммерсанта и учительницы в маленьком китайском городке Кульджа в долине реки Или, отделенном от Советского Союза пограничной заставой, а от Китая - ТяньШанем. Учился в татарской школе, затем окончил Пекинскую академию художеств. В 1963 году семья переехала в Чимкент, а Равил продолжил свое образование в Ташкентском художественно-театральном институте. Халилов также работал в технике акварели, его манера отличалась особой изысканностью, особенно в пейзажах, тонких и поэтичных. В 1978-м он переехал в Москву. Впечатления детства и юности повлияли на творчество Халилова не меньше, чем образование. Мастер приобрел известность как иллюстратор множества книг - эпоса, фольклора, детских сказок разных народов мира. Например, в 1986 году в издательстве «Малыш» вышла небольшая книжка - стихотворение Габдуллы Тукая «Мальчик с дудочкой» с иллюстрациями Халилова. Он обращался и к живописи, в поздние годы создал несколько серий тревожных, драматичных станковых полотен, одна из которых посвящена Чернобыльской трагедии. Незадолго до смерти художник начал работу над иллюстрациями к книге «Религиозная поэзия татар», которая, к сожалению, осталась незавершенной.

Второй раздел экспозиции был более обширным. В нем представлены живущие в Москве живописец Амир Тимергалеев и скульптор Тагир Субханкулов, художник из СанктПетербурга Марат Вафин, пермский скульптор Альфиз Сабиров, учившийся в Латвии и часто бывающий там Рамин Нафиков. Несколько татарских художников живут в Уфе - Анвар Кашаев, Ринат Миннебаев, участники группы «Чингисхан» Василь Ханнанов, Ринат Харисов, Мидат Мухаметов, Расих Ахметвалиев. В Уфе работала Адия Ситдикова.

Живописец Амир Тимергалеев родился в 1955 году в Казани. После учебы в Казанском художественном училище продолжил образование в Московском институте им. В. И. Сури- 
кова. Его манеру можно обозначить как «свободную фигуративность»; работы камерные, при этом яркие по колориту. Он пишет пейзажи, в том числе городские, натюрморты, портреты. Импровизируя, творчески перерабатывает наследие мировой культуры. Сегодня Амир Тимергалеев живет и работает в Москве, он уверенно входит в круг ярких представителей не только татарского, но и европейского художественного мира. Одна из работ Тимергалеева, «Пейзаж. Казань», где изображена улица Баумана, особенно привлекла зрителей, напомнив им о недавнем прошлом. Художник написал работу в 2008 году - судя по всему, по воспоминаниям. По вывескам магазинов пришедшие на выставку жители Казани определили, что так улица выглядела немного раньше, в конце 1990-х годов.

Тема творчества петербуржца Марата Вафина (род. 1962) - Волжская Булгария, наследником культуры которой стал татарский народ. Художнику интересно все, что связано с историей этого некогда могущественного государства, в том числе его религия - тенгрианство. Вафин по большей части работает сериями, создавая многочастные композиции на одну тему. Его живопись пастозная, рельефная, и для укрепления живописной поверхности он иногда использует чеснок, подмешивая его сок в краски. В экспозиции было представлено четыре работы из двадцатичастного живописного полиптиха «Звездная река». Художник сделал десятки подготовительных рисунков к каждой работе в поисках единственно верного композиционного решения. Работы Вафина много раз были показаны в Казани. В 2016 году картины серии «Восстановление Большого булгарского минарета. Пять намазов» украсили выставку «Путешествие Ибн Фадлана: волжский путь от Багдада до Булгара» в центре «ЭрмитажКазань».

Татарские художники из Башкортостана были представлены на выставке несколькими именами. Пожалуй, самое известное творческое объединение Уфы - группа «Чингисхан». Союз возник в 1990 году и существует до сих пор, сейчас им руководит Василь Ханнанов. Его работы не раз демонстрировались в столице Татарстана. Василь родился в 1956 году в городе Октябрьский (БАССР). Творчество Ханнанова - благодатная почва для искусствоведческих интерпретаций. Но, по словам художника, все работы - это его собственная история, а выбор пластических решений определяется тем, что его мучает и беспокоит в определенный период жизни. Результат своего труда он оценивает строго, внимательно прислушиваясь к реакции зрителей. Во всем его творчестве чувствуется свобода. Живопись и графика Ханнанова стилистически разнообразны - от реализма до беспредметности. Он обращается к античным мифам, Корану, Ветхому и Новому Завету, к народному искусству. На протяжении творческого пути художник часто использовал общетюркские мотивы, а также образы, почерпнутые из истории Татарстана. На выставке были показаны две живописные работы художника 1990-х годов: символическая «Композиция № 126 (Великая степь)» из цикла «Рождение мифа» и «Сююмбике». Фактурная, выполненная в темной лаконичной цветовой гамме «Сююмбике» привлекала посетителей выставки не только красотой исполнения. Художнику удалось создать загадочный образ, тайну, скрытую в глубине веков. В образе Сююмбике нет той мягкости и лиричности, которую мы видим на картине Чингиза Ахмарова. Женщина сидит на ковре в абстрактном пустом пространстве, ее глаза прикрыты. Она прижимает к себе сына, оберегающим жестом закрывает руку мальчика своей ладонью с длинными изящными пальцами, унизанными перстнями. Сын Утямышгирей, чье лицо напоминает фаюмский портрет, в упор смотрит на зрителя. Пока еще открытый миру ребенок - и отвернувшаяся от этого мира, задумчивая, много пережившая молодая женщина...

По-своему трактует образ Сююмбике другой уфимский мастер - Ринат Харисов. Необычное для такой темы плакатное решение усиливает драматизм сюжета. Плачущая царица казанская взлетает ввысь, пересекая падающую под острым углом башню, названную в ее честь. Общее ощущение трагизма усиливается контрастом острых углов, пересекающихся диагоналей и элементов татарского цветочного орнамента, который можно встретить во многих работах Харисова. Сююмбике становится символом, маркером эпохи. Такие же символы, но уже религиозные, художник пишет в работе «Казанский кремль»: Спасская башня с пятиконечной звездой, христианский собор и башня Сююмбике, увенчанная полумесяцем - эмблемой ислама, пиками врезаются в небо, пересекая друг друга.

Ринат Харисов, также участник группы «Чингисхан», родился в 1953 году в деревне Ленин-Буляк Бураевского района БАССР. Взяв 
за основу творчества примитивистскую стилистику, художник опирается на традиции татарского народного декоративно-прикладного искусства. Вышивка, роспись домов, шамаиль с их орнаментальностью - знакомая автору с детства сельская и городская провинциальная культуры середины XX века. Важную роль в произведениях Харисова играют тексты на русском, татарском и арабском языках, напоминающие вывески и транспаранты. Так, в работе «Черно-белое кино» (2002) надпись на татарском переводится следующим образом: «Сегодня в нашем сельском клубе будут показывать картину „Мистер Питкин в тылу врага“. Товарищи, кино очень хорошее, приходите посмотреть!»

Призрачные всадники, прекрасные дамы и далекие города - сюжеты работ Расиха Ахметвалиева. Он родился в 1956 году в деревне Бекеево Чишминского района Башкирии. Расих Ахметвалиев - художник-визионер. Его камерные холсты - это загадочные видения, в которых эстетика и гармония становятся преобладающими качествами. На выставке были показаны характерные по сюжетам и манере письма мифические всадники, однако работы оказались необычно яркими по колориту для этого художника. Всадники Ахметвалиева - не персонификация силы, мощи, воинственного начала, их содержание гораздо сложнее и многозначнее. Это образы и тюркские, и одновременно общемировые. Их можно сравнить с миражами и возникающими иногда в облачном небе видениями, в которых мы пытаемся распознать знакомые очертания. Расих экспериментирует с цветом и светом. Его полотна фактурны и многослойны. Гладкая поверхность сочетается с будто вылепленными формами. С помощью прозрачных лессировок в сочетании с пастозными мазками он создает перламутровую поверхность, в которой оттенки зеленого, голубого, желтого мягко переходят друг в друга. Фактурой и легкостью его работы напоминают полустертые фрески, украшавшие древние жилища. Создавая свои холсты, Расих чаще обращается к светлым пастельным оттенкам.

Главной темой творчества живописца и графика Мидата Мухаметова (род. 1955) вот уже несколько десятилетий остается степь. Его родина - село Мустафино Шарлыкского района Оренбургской области. Мухаметов, выросший в степных просторах, обладает особым пространственным восприятием, которое ярко проявляется в его медитативной живописи. В сво- их работах он постепенно переходит от пейзажей определенных мест к более широкому пониманию степи, создавая образы сродни космическим. Балансируя на грани реализма и абстракции, Мидат превращает все, что встречается путнику: человеческие фигуры, могильные камни - в антропоморфные геометризованные знаки, и весь ландшафт становится единой ритмически организованной субстанцией. Мидат тяготеет к монохромности, характерным для степи темно-зеленым, коричневым, охристым оттенкам. Художнику чужда патетика. Степь меланхолична, тягуча в его работах. Однако меланхолия здесь - не человеческая эмоция, а скорее внутреннее свойство пейзажа. Степь - благодатный образ для абстракции. По сути, она беспредметна сама по себе. Это загадочная сущность, живущая по своим законам.

Живописец и график Анвар Кашаев родился в 1949 году в селе Акбулат Федоровского района БАССР. В 15 лет Анвар уехал в Среднюю Азию. В Чимкенте (Южный Казахстан) работал бетонщиком, затем был каменщиком в Ташкенте, участвовал в восстановлении города после землетрясения в 1967 году, работал на стройке в Душанбе. Там он поступил вольнослушателем в художественное училище, а в 1969 году вернулся в Башкирию и завершил образование в Уфимском художественном училище. Живопись Кашаева неяркая, камерная и поэтичная. Любимый жанр - безлюдные пейзажи. Главные их герои - природа, прозрачный воздух и сам художник, подчиненный этому природному ритму как неотьемлемая часть мироздания: «не асфальт, а небо и земля рождают художников». Источником вдохновения для него стал уголок земли у южных отрогов Уральских гор. Он обращается к одним и тем же мотивам и пишет их в любое время года, пребывая в разном настроении, и всякий раз возникает новая, не похожая на другие работа. Так Хокусай делал свои «Тридцать шесть видов Фудзи». Анвару близко искусство дальневосточных художников. А еще рядом с его мольбертом всегда открыт альбом древнерусской живописи. Анвар считает, что иконы и работы китайских мастеров близки по духу.

Ринат Миннебаев (род. 1964) - один из ведущих мастеров современного искусства Поволжья и Приуралья, хорошо известный в Казани. Панно, выполненные в уникальной технике из бумаги ручного литья (серия «Путешествие Ибн Фадлана на реку Итиль») органично вписались в археологическую выставку «Путешествие Ибн-Фадлана: Волжский путь от Ба- 
гдада до Булгара», проведенную в 2015 году в залах центра «Эрмитаж-Казань». Миннебаев выпускник художественно-графического факультета Башкирского пединститута. Его работы насыщены условными, но полными потаенного смысла элементами, отсылающими к архетипам культуры древних тюрков. На выставке представлены ранние офорты из серии «Маски богов». В них художник передает мистическую связь человека и природы. Ринат с юности увлечен археологией. В своих офортах, населенных образами первопредков, автор последовательно шел ко все более отвлеченным лаконичным знакам. Он трансформирует восприятие времени, переносит зрителя в эпоху глубокой древности.

Необычна судьба художницы Адии Ситдиковой (1913-2000), единственной женщиныхудожницы на выставке. Она начала рисовать, когда ей было за сорок, но смогла стать профессиональным живописцем.

Адия Ситдикова родилась в Татарстане, в деревне Мордва Агрызского района. В 16 лет она покинула свою деревню. Уехала в Среднюю Азию, потом в Москву. В 1934 году попала в Уфу, где и осталась. В 1950-х Ситдикова устроилась в Художественный фонд подсобной работницей, и это определило ее дальнейшую жизнь. Уже в зрелом возрасте она между мытьем окон и перестановками чужих холстов начала брать первые уроки живописи в изостудии. Вскоре ее талант заметили, работы стали показывать на выставках. Художница интуитивно обрела собственный стиль, основанный на этнических мотивах, близких ей с детства, - это татарские полотенца, и занавески с народными орнаментами, башкирский мед и чак-чак - символы домашнего уюта и благополучия. Кстати, Адия была прекрасной вышивальщицей и портнихой. Сейчас имя Адии Ситдиковой, удостоенной множества государственных наград, входит в число самых значимых художников Башкортостана.

У зрителей, пришедших на выставку и знакомых с работами местных казанских художников, мог возникнуть вопрос: почему в экспозиции, рассказывающей о художниках, работающих вне Татарстана, представлены работы Рамина Нафикова. Рамин (род. 1967) живет в Казани. Он потомственный живописец, его отец Ханафи Нафиков - заслуженный художник Республики Татарстан. После окончания Казанского художественного училища Рамин продолжил образование в Латвийской академии художеств, и это во многом определило его творческое развитие. Художник подолгу путешествует. Постоянное движение между Западом и Востоком (Казань - Рига - Вена) стало не только выставочной географией Рамина, но и своего рода художественной стратегией. В творчестве Нафикова европейский артистизм соединяется с восточной энергией. Работы Рамина энергичны по цвету и композиции. На первый взгляд они кажутся полной абстракцией. Однако в этих, казалось бы, хаотичных линиях и цветовых пятнах зрители порой интуитивно, не глядя на этикетку с названием, угадывали сюжеты. Сам художник определяет свой стиль как «экспрессивный формализм».

Центральное пространство экспозиции было посвящено пластическим формам. Фонд Марджани привез на выставку работы двух скульпторов: живущего в Москве уфимца Тагира Субханкулова и работающего в Перми Альфиза Сабирова.

Тагир Субханкулов родился в 1954 году в деревне Еремеево Чишминского района Башкирии. По окончании художественно-графического факультета Московского пединститута им. В. И. Ленина он решил остаться в столице. Тагир с одинаковым успехом работает с бронзой, камнем, деревом, пластиком и глиной. Он создает и миниатюры, и городские монументы, и реалистические фигуры, и абстрактные формы. $\mathrm{B}$ его работах можно найти отголоски искусства как древнего Египта, так и модерна начала прошлого столетия с его текучестью форм и виртуозной игрой силуэтов, стремлением запечатлеть мгновение в выражении лица и движении тела. Красота женского тела - одна из приоритетных тем в творчестве Тагира. Моделью для некоторых работ, в том числе показанных на выставке, стала жена скульптора. «Моя бурятка», - нежно говорит он о ней. Его модели не обладают идеальной внешностью, они земные, целомудренные в своей наготе. Он не стремится достичь портретного сходства. Это, скорее, отвлеченные образы, воплощающие обобщенное представление о природном женском начале. Тагир мастерски использует фактуру камня, дерева, бронзы, не заглаживая поверхность до глянца. Даже бронза, материал холодный по своей природе, обретает у него теплоту.

Тагир стал автором нескольких замечательных произведений, созданных для городских пространств и общественных институций. Он автор скульптурной композиции «Русалка», ус- 
тановленной перед Национальным культурным центром города Казани, создатель статуэтки приза Международного кинофестиваля мусульманского кино «Золотой Минбар», приза Фонда духовного возрождения «Рухият», скульптуры-символа Татарстана «Акбарс».

Скульптор Альфиз Сабиров, самый молодой участник выставки, родился в 1985 году в маленьком прикамском селе Ишимово. Выпускник Российской академии живописи, ваяния и зодчества Ильи Глазунова, он в 2017 году стал лауреатом премии Министерства культуры РТ имени Баки Урманче. Работы Сабирова уже получили известность и в России, и за рубежом (см.: [Хабутдинова, Замалиева]). В работах Альфиза тесно переплетаются национальные мотивы, мифология и даже космические формы. Это мир фантастических животных, героев и богов, который соприкасается с современностью. Художник обращается как к мелкой пластике, создавая произведения из бронзы, граничащие с ювелирным искусством, так и к достаточно крупным формам. Альфиз экспериментирует, сочетая порой в одной скульптуре различные материалы. Он признается, что пока не может дать точного определения своему стилю: «Наиболее интересный вариант - „Новый артефакт“. Он основан на древних артефактах, тех вещах, которые нашли на раскопках, которые когда-то были предметами ритуалов и дошли до нас уже искусством в виде осколков или фрагментов. Структурные элементы легенд и мифов я рассматриваю как состояние жизни. Как часть чего-то большего».

Выставка «Родник любви и вдохновения. Произведения татарских художников из коллекции Фонда Марджани» наглядно продемонстрировала, насколько разнообразно искусство татарских мастеров, на какое-то время покидающих родину или родившихся за пределами Татарстана. Одни художники концентрируются на особенностях национального мировоззрения и создают собственный этнический микрокосм с его историей, природой, мифологией, языком и прочими атрибутами. Другие расширяют границы художественного мира до общетюркских образов. Несомненно, на творческие личности влияет среда. Это и путешествия, смена места жительства и, конечно, воспоминания детства и юности, народное творчество, культура народа, к которому принадлежат художники. Этим объясняется цельность экспозиции выставки, состоявшей из представителей татарской куль- туры разных поколений, разных судеб и взглядов.

\section{Литература}

Баки Урманче. Живопись. Графика. Скульптура. Литературное наследие. К 120-летию со дня рождения художника. Казань: Заман, 2017. 480 с.

Гилязов И. А. На другой стороне. Коллаборационисты из поволжско-приуральских татар в годы Второй мировой войны. Казань: Мастер-Лайн, 1998. $252 \mathrm{c}$.

Машакова А. К., Хабутдинова М. М. К вопросу об этнической самоидентификации татар Казахстана (на материале лирики современных татарских поэтов). // Tatarica. 2016. № 1. С. 59-71.

Нигматуллина Ю. Г. «Запоздалый модернизм» в татарской литературе и изобразительном искусстве. Казань: Фән, 2002. 175 с.

Нигматуллина Ю. Г. Татавангард как компонент «срединной культуры» // Tatarica. 2014. № 1(2). С. 156-178.

Нигматуллина Ю. Г. Татавангард: национальная идентичность и евразийское самосознание // Tatarica. 2014. № 2(3). C. 185-203.

Уфа. Точка возврата / сост. М. Филатова. М.: Фонд Марджани, 2016. 215 с.

Хамидуллин Б. Л. Шигабутдин Марджани: от среднеазиатских «университетов» к идеологии татарской нации «нового времени» // Tatarica. 2018. №1(10). С. 157-163.

Хабутдинова М. М., Замалиева Л. Ф. Сплав архаики и современности в творчестве скульптора Альфиза Сабирова / М. М. Хабутдинова, Л. Ф. Замалиева // Tatarica. 2019. № 13(2). С. 126-139.

Художники Республики Башкортостан: альбомкаталог. Уфа, 2011.375 с.

Чингиз Ахмаров. М.: Галеев Галерея, 2010. 280 с.

Хәбетдинова М. М. Ф. Бәйрәмованың «һижрәт» (2017) романында татар эмиграциясе темасы // Фәнни Татарстан. 2019. № 2. Б. 35-45.

Usmanova L. The Turk-Tatar Diaspora in Northeast Asia: Transformation of Consciosness; A Historical and Sociological Account Between 1898 and the 1950s / L. Usmanova. Tokyo: Rakudasha,2007. 367 p.

Safin M. F, Khabutdinova M. M, Khabutdinov A. J. The theme of muhajirlik in tatar prose (El tema del muhajirlik en la prosa tartara) // Opcion. 2018. Vol. 34, Is. 86. P. $119-126$.

Faezova L. R., Khabutdinova M. M., Gaynyllina G. $R$. The Emigration Theme In Tatar Literature // Modern journal of language teaching methods. 2018. Vol. 8, Is. 9. P. 66-71.

\section{Список иллюстраций}

1. Адия Ситдикова. Натюрморт с вышитым полотенцем. 1981. Бумага, гуашь, белила. 37×31,5. Фонд Марджани

2. Василь Ханнанов. Сююмбике-2. 1994. Холст, масло. 146,5х97. Фонд Марджани 
3. Амир Тимергалеев. Пейзаж. Казань. 2008. Холст, масло. 60х80. Фонд Марджани

4. Анвар Кашаев. Забытая деревня. 2006. Холст, масло. 87x121. Фонд Марджани

5. Марат Вафин. Красный конь. Часть 14 полиптиха Звездная река. 2011. Холст, масло. 50x150. Фонд Марджани

6. Баки Урманче. Дети в юрте. 1949. Холст, масло. 60х50. Фонд Марджани

7. Марат Садыков. Вечерний разговор. 1997. Бумага, акварель. 49х60. Фонд Марджани

8. Мидат Мухаметов. Идущая. 1995. Холст, масло. 65x110. Фонд Марджани

9. Равил Халилов. Девушка в красном. 1972. Бумага, гуашь. 69х59. Фонд Марджани
10. Ринат Харисов. Сююмбике царица Казанская. 2009. Холст, акрил. 147х89. Фонд Марджани

11. Рамин Нафиков. И кораблик плывет. 2007. Холст, масло. 110х164. Фонд Марджани

12. Чингиз Ахмаров. Сююмбике с сыном Утямышгиреем. 1992. Холст, темпера. 100х80. Фонд Марджани

13. Ринат Миннебаев. Белая волчица. Из серии Маски богов. 1995. Цветной офорт, акватинта. 41,5x53,5. Фонд Марджани

14. Альфиз Сабиров. Пораженный. 2018. Бронза. 22х14,5х10. Фонд Марджани

15. Тагир Субханкулов. Планета Земля. 2005. Бронза. 43х12.13. Фонд Марджани

\title{
“МӘХӘББӘТ һӘМ ИЛЬАМ ЧИШМӘСЕ” КУРГӘЗМӘСЕ: НИЯТТӘН -- ЧЫНБАРЛЫККА
}

Мария Юрьевна Филатова, Шәрык дәүләт музее, Россия, 119019, Мәскәү ш., Никита бульвары, 12 нче А йорты, fima2018@yandex.ru.

\begin{abstract}
Мәкалә ТАССРның 100 еллыгына багышланган “Мәхәббәт һәм илһам чишмәсе” күргәзмәсендәге рәссамнар әсәрләренең үзенчәлеген ачуга багышланган. Бу “Казан Кремле” дәүләт тарихархитектура һәм сәнгать музей-тыюлыгы һәм Мәскәүдәге Шиһабетдин Мәржани исемендәге фондның уртак проекты. Күргәзмәдә тәкъдим ителгән хезмәтләрдә рәссамнарның милли тәңгәллекне гәүдәләндерү үзенчәлекләрен ачыклау әлеге тикшерүнең максаты булып тора. Рәссамнарның бер өлеше, дөньяга милли карашлар үзенчәлекләренә игьтибар итеп, тарихы, табигате, мифологиясе, теле һәм башка атрибутлары булган кечкенә этник дөньяларын тудыра, ә икенчеләре - сәнгать дөньясының чикләрен гомумтөрки образларга кадәр киңәйтәләр.
\end{abstract}

Төп төшенчәләр: татарлар, сынлы сәнгать, Шиһабетдин Мәржани исемендәге фонд, татар рәссамнары, милли тәңгәллек.

\section{Иллюстрацияләр исемлеге}

1. Адия Ситдыйкова. Чиккән сөлге белән натюрморт. 1981. Кәгазь, гуашь, акшар. 37х31,5. Мәржани фонды.

2. Вәсил Ханнанов. Сөембикә-2. 1994. Киндер, майлы буяу. 146,5х97. Мәржани фонды.

3. Әмир Тимергалиев. Пейзаж. Казан. 2008. Киндер, майлы буяу. 60х80. Мәржани фонды.

4. Әнвәр Кашаев. Онытылган авыл. 2006. Киндер, майлы буяу. 87х121. Мәржани фонды.

5. Марат Вафин. Кызыл ат. Полиптихның 14нче өлеше. Йолдызлы елга. 2011. Киндер, майлы буяу. 50x150. Мәржани фонды.

6. Бакый Урманче. Тирмәдәге балалар. 1949. Киндер, майлы буяу. 60х50. Мәржани фонды.

7. Марат Садыйков. Кичке әңгәмәләр. 1997. Кәгазь, акварель. 49х60. Мәржани фонды.

8. Мидат Мөхәммәтов. Баручы. 1995. Киндер, майлы буяу. 65x110. Мәржани фонды.
9. Равил Хәлилов Кызыл киемле кыз. 1972. Кәгазь, гуаш, 69х59. Мәржәни фонды.

10. Ринат Харисов. Казан патшабикәсе Сөембикә. 2009. Киндер, акрил буяу. 147х89. Мәржани фонды.

11. Рамин Нәфыйков. Кораб йөзә. 2007. Киндер, майлы буяу. 110х164. Мәржани фонды.

12. Чыңгыз Әхмәров. Сөембикә улы Үтәмешгәрәй белән. 1992. Киндер, темпера. 100х80. Мәржани фонды.

13. Ринат Миңнебаев. Ак бүре. Аллалар битлекләре сериясеннән. 1995. Төсле офорт, акватинта. 41,5х53,5. Мәржани фонды.

14. Әлфиз Сабиров. Жиңелгән. 2018. Бакыр. 22x14,5х10. Мәржани фонды.

15. Таһир Сөбһанкулов. Жир планетасы. 2005. Бакыр 43x12.13. Мәржани фонды. 


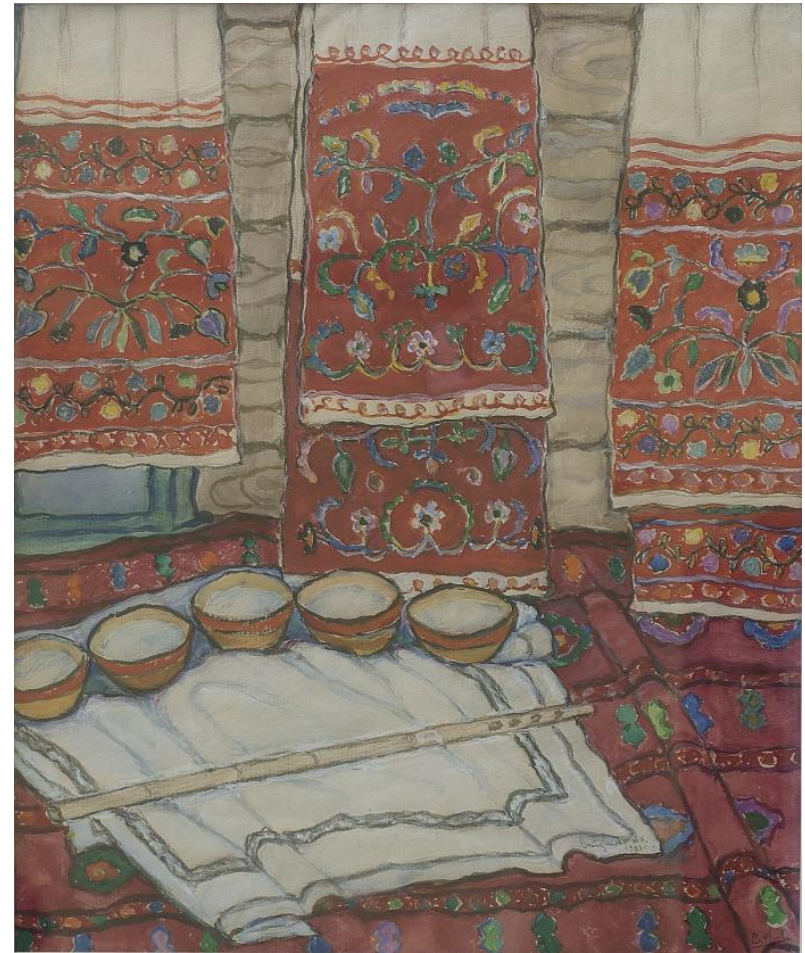

№1

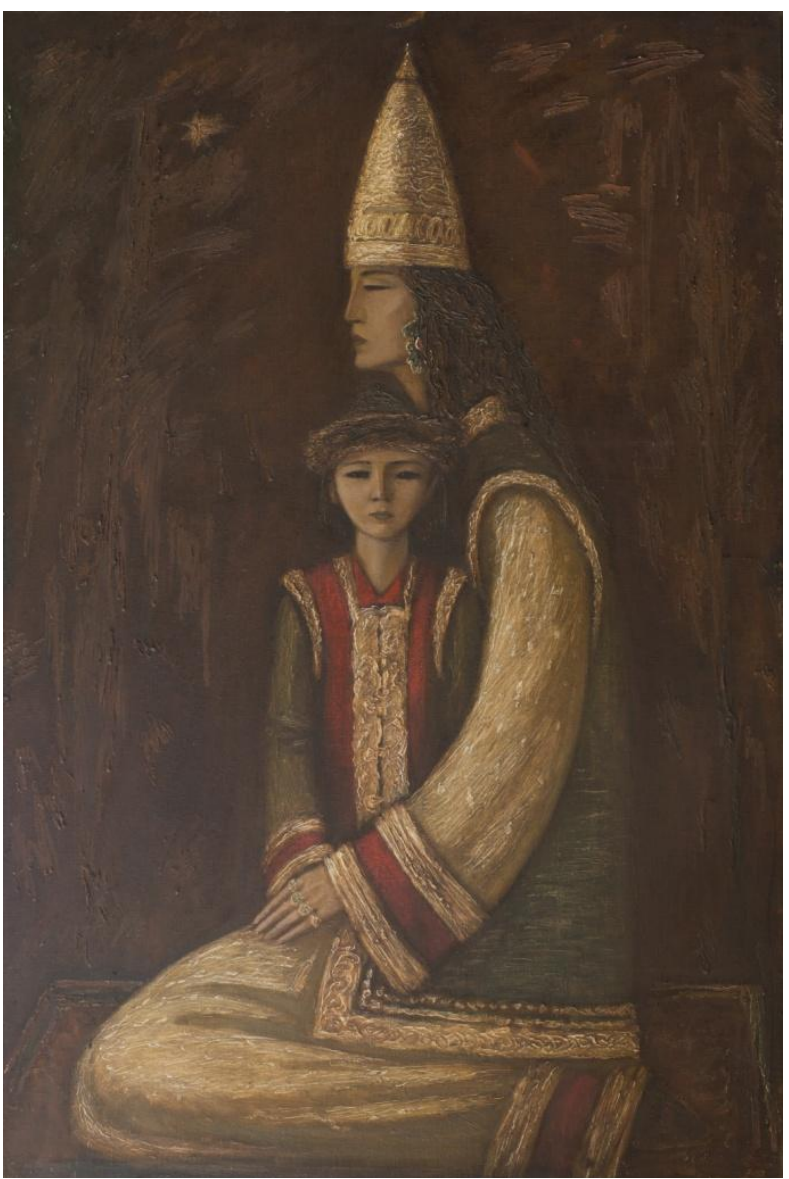

№2 

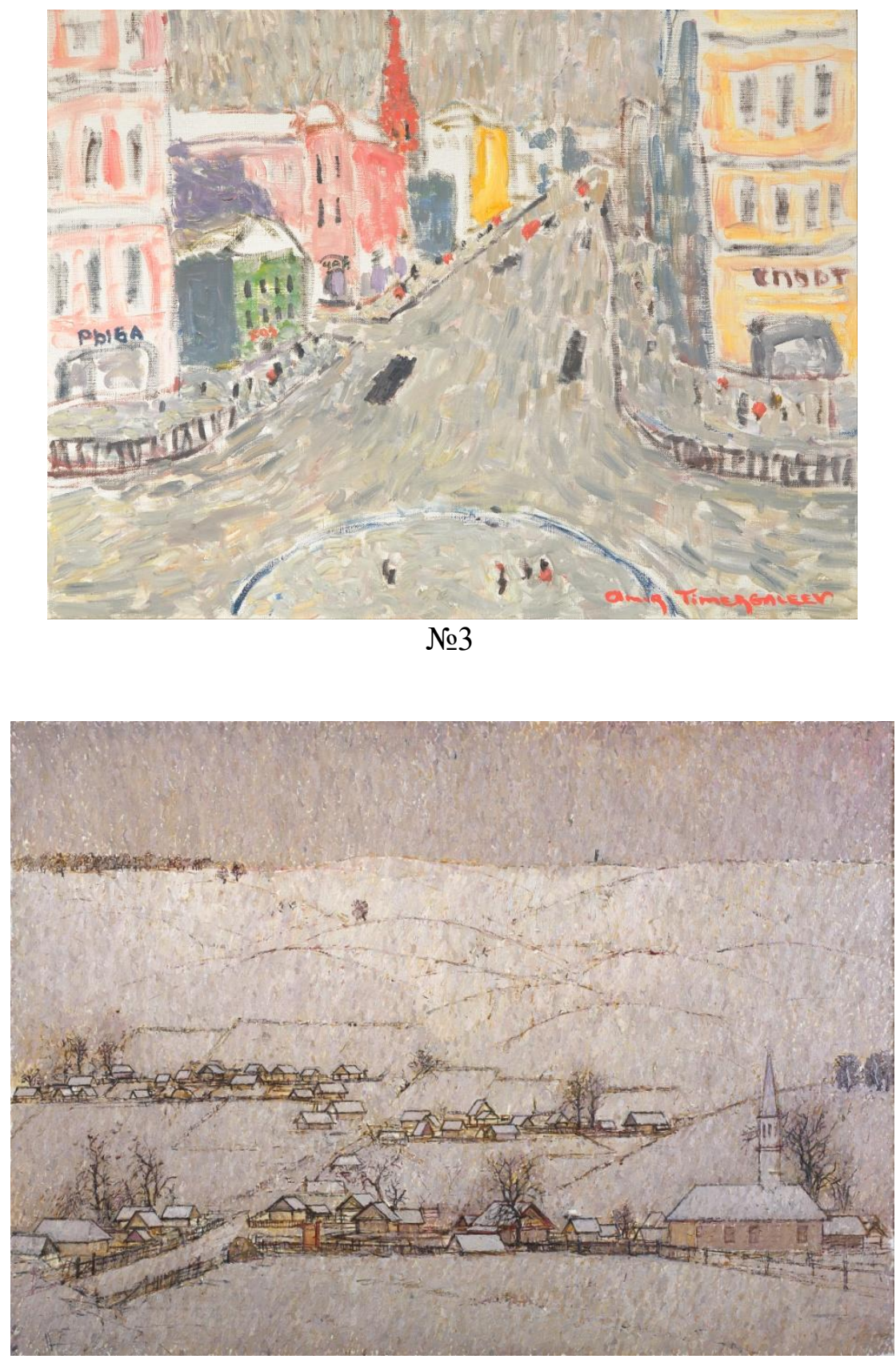

№4

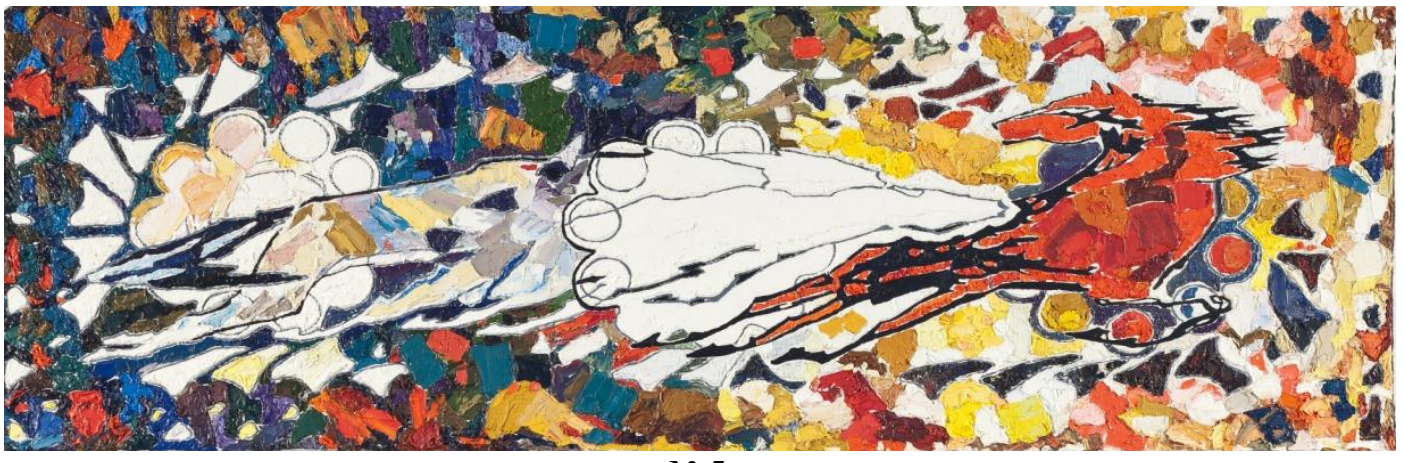

№5 


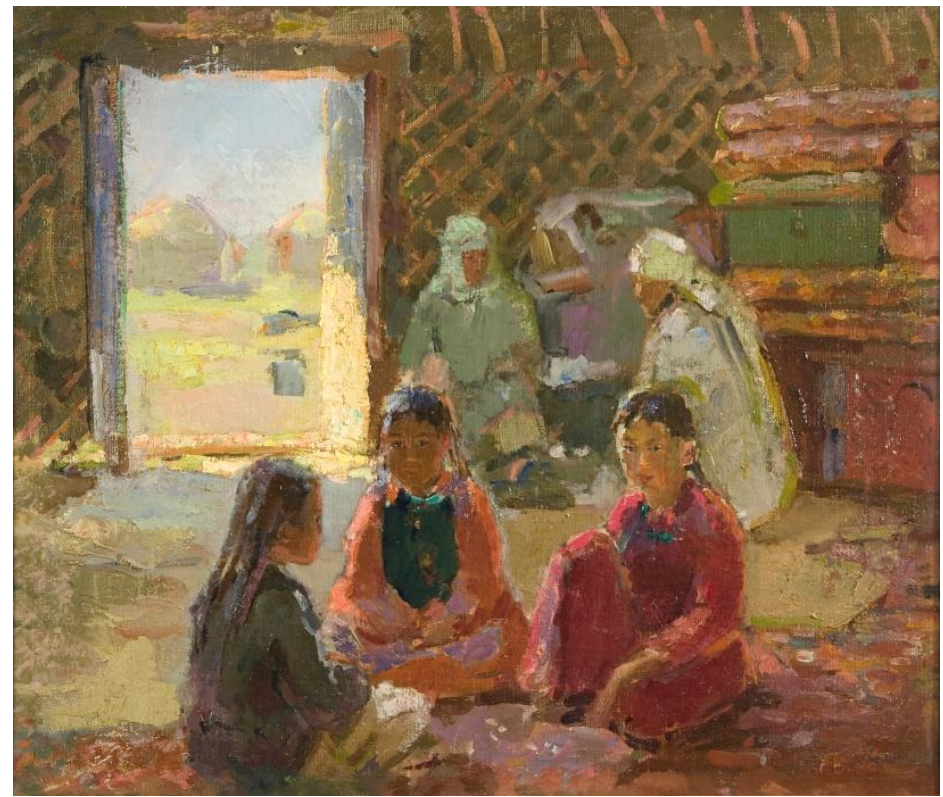

№6

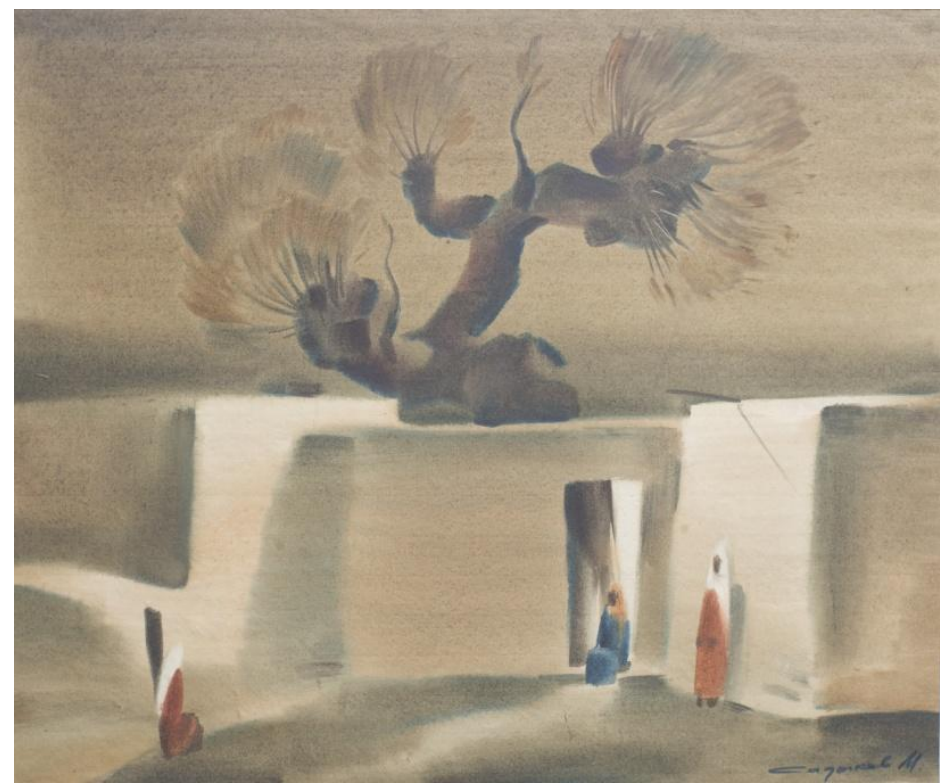

№7

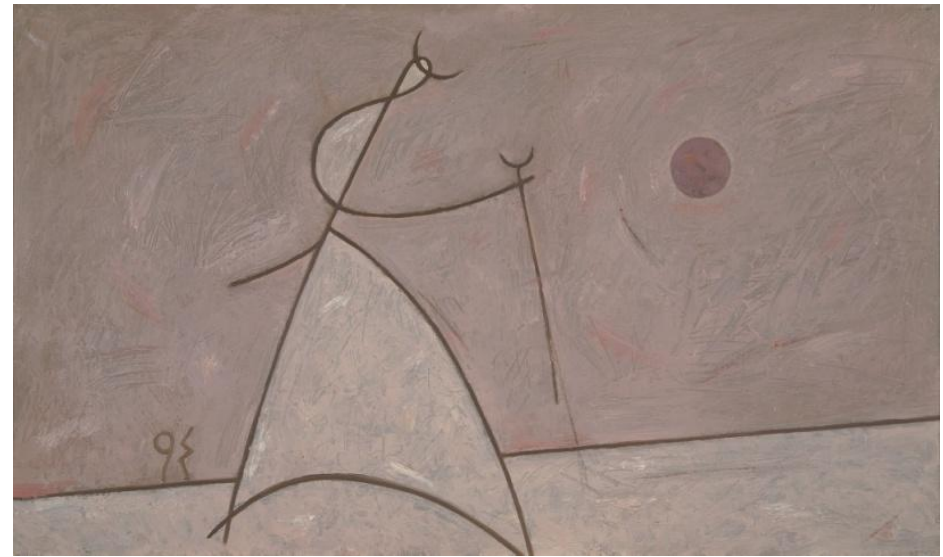

№8 


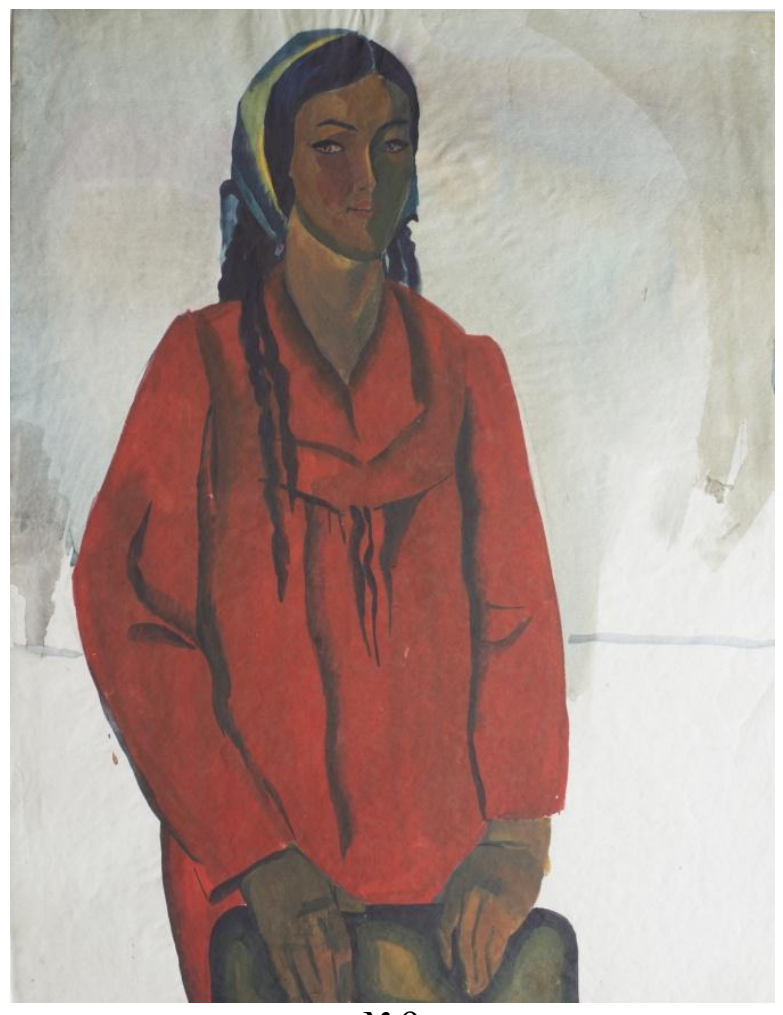

№9

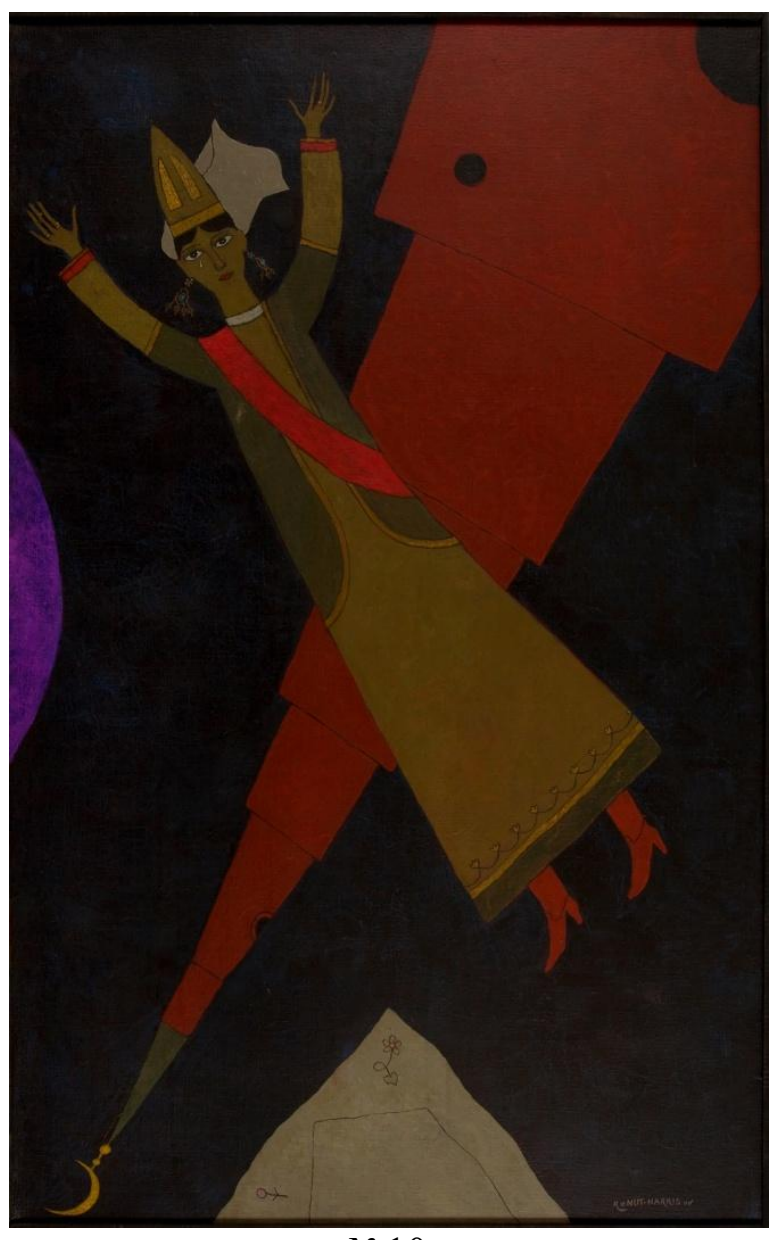

№10 

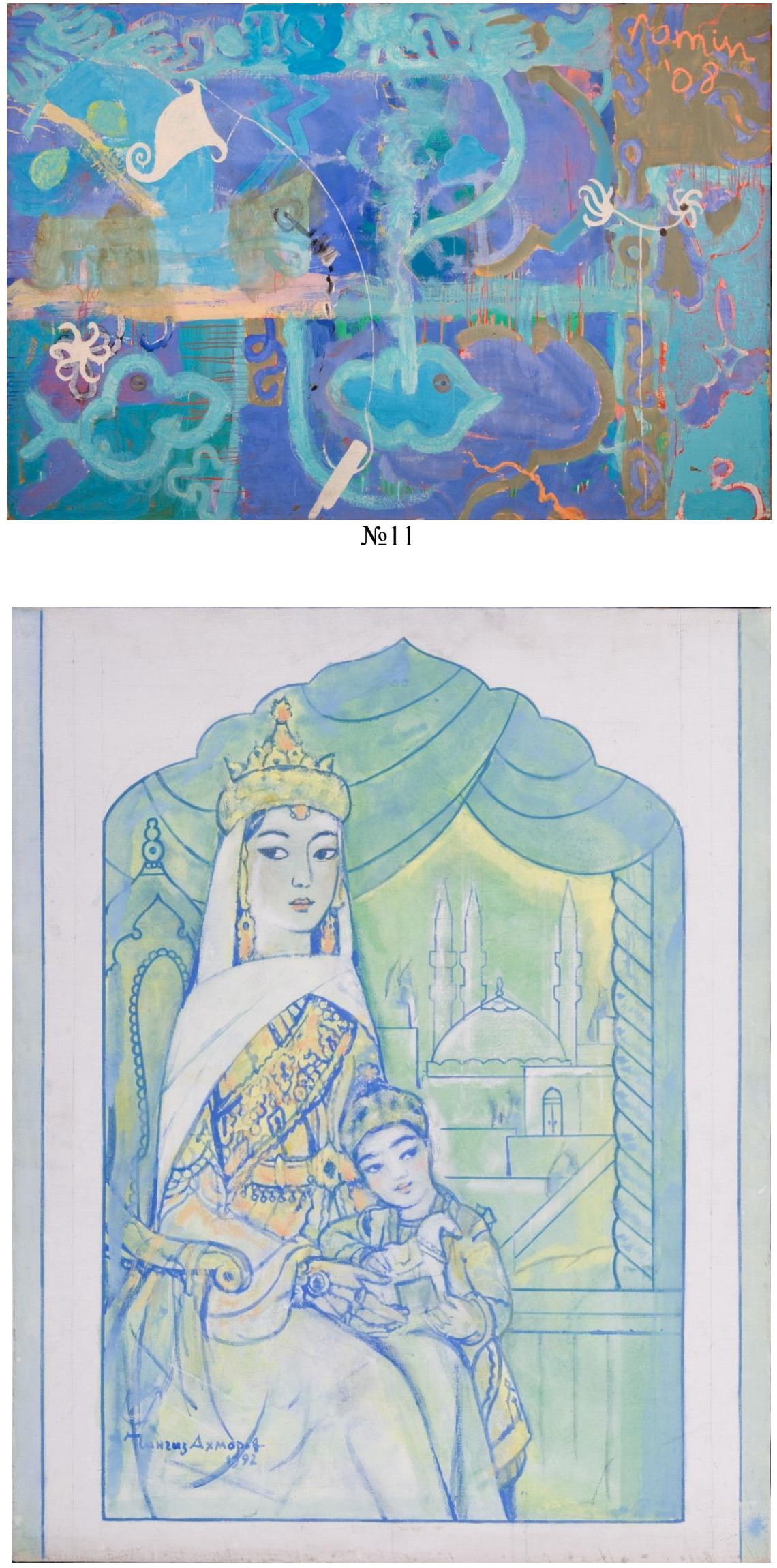

№12 


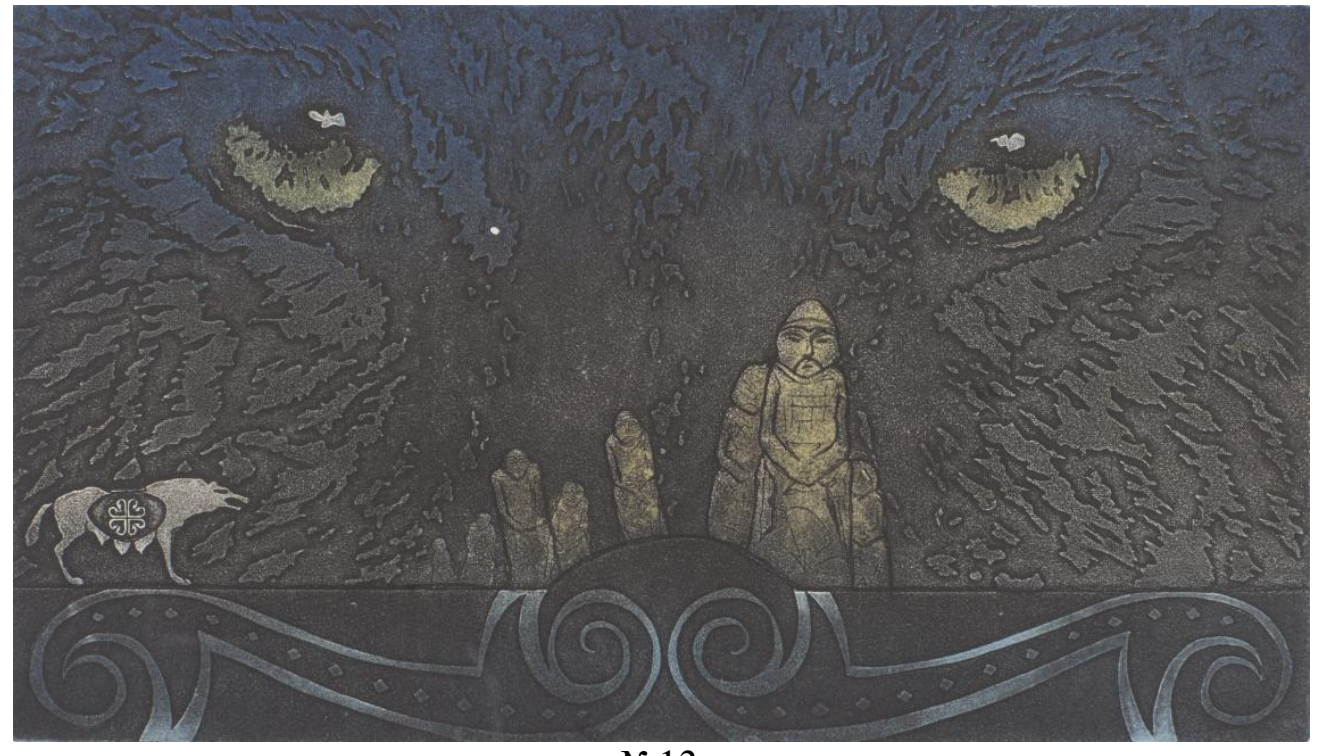

№13

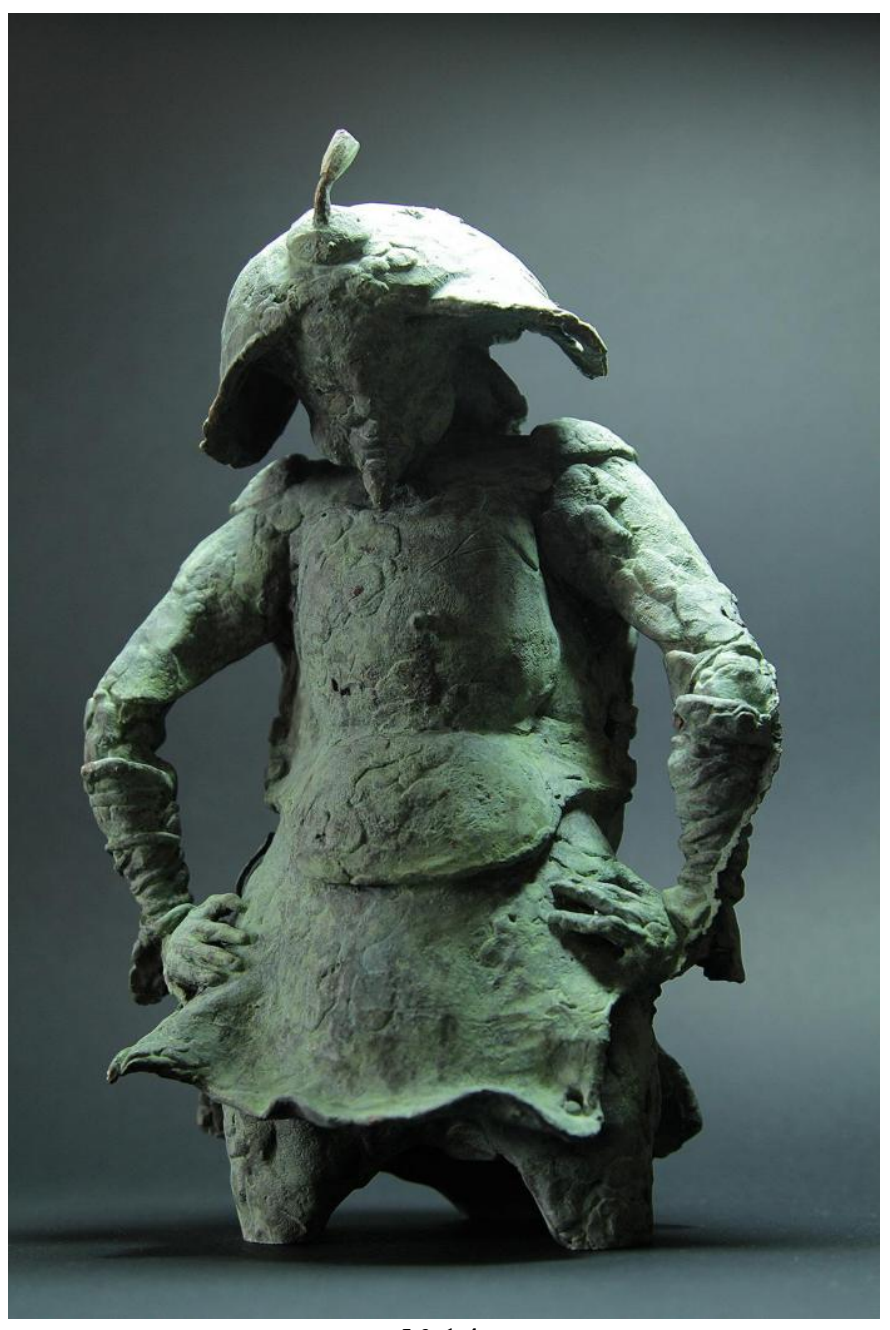

№14

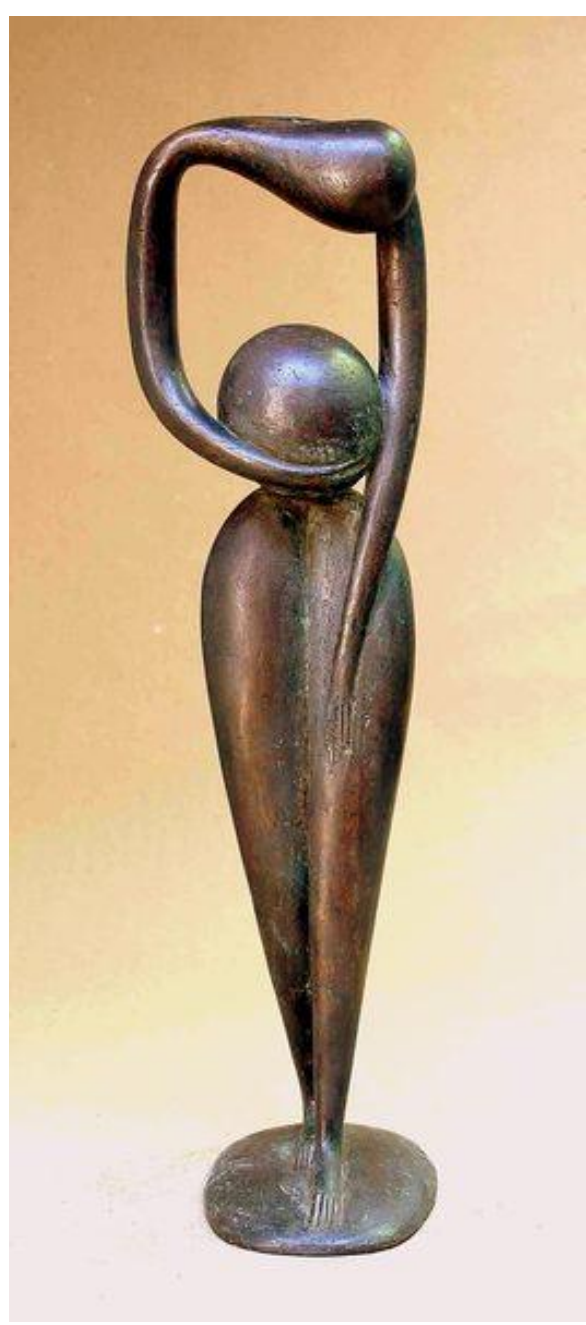

№15 